\title{
MULTI-TAXA ISOTOPIC INVESTIGATION OF PALEOHYDROLOGY IN THE LOWER CRETACEOUS CEDAR MOUNTAIN FORMATION, EASTERN UTAH, U.S.A.: DECIPHERING EFFECTS OF THE NEVADAPLANO PLATEAU ON REGIONAL CLIMATE
}

\author{
CELINA A. SUAREZ, ${ }^{* 1}$ LUIS A. GONZÁLEZ, ${ }^{1}$ GREGORY A. LUDVIGSON, ${ }^{2}$ JAMES I. KIRKLAND, ${ }^{3}$ RICHARD L. CIFELLI, ${ }^{4}$ AND \\ MATTHEW J. KOHN ${ }^{5}$ \\ ${ }^{I}$ Department of Geology, University of Kansas, 1475 Jayhawk Boulevard, Lawrence, Kansas 66045, U.S.A. \\ ${ }^{2}$ Kansas Geological Survey, University of Kansas, 1930 Constant Avenue, Lawrence, Kansas 66047, U.S.A. \\ ${ }^{3}$ Utah Geological Survey, 2594 West North Temple, P.O. Box 146100, Salt Lake City, Utah 84114, U.S.A. \\ ${ }^{4}$ Sam Noble Oklahoma Museum of Natural History, 2401 Chautauqua Avenue, Norman, Oklahoma 73072, U.S.A. \\ ${ }^{5}$ Department of Geosciences, Boise State University, 1910 University Drive, Boise, Idaho 83725, U.S.A. \\ e-mail: casuarez@uark.edu
}

\begin{abstract}
We investigate the regional climatic effects of the formation of the "Nevadaplano" plateau during the Sevier Orogeny in an overall warming world. Paleohydrology was reconstructed from $\mathbf{5 9 0}$ individual measurements of phosphate $\mathbf{O}$ isotopes in continental faunas of the Lower Cretaceous Cedar Mountain Formation, Utah, U.S.A. Semi-aquatic (turtles, crocodiles) and terrestrial (dinosaurs) taxa are compared to coeval pedogenic carbonates to interpret changing water sources over time. Samples were grouped into four stratigraphic faunas (lower Yellow Cat, upper Yellow Cat, Ruby Ranch, and Mussentuchit members). Resulting isotopic values were converted to $\delta^{18} \mathrm{O}_{w}$ values using established $\delta^{18} \mathrm{O}_{\mathrm{p}}-\delta^{18} \mathrm{O}_{\mathrm{w}}$ and $\delta^{18} \mathrm{O}_{\mathrm{c}}-\delta^{18} \mathrm{O}_{w}$ relationships. At a formation scale, turtles $\left(\delta^{18} \mathrm{O}_{\mathrm{p}}=14.1\right.$ to $15.7 \% \mathrm{~V}$-SMOW) and crocodiles $\left(\delta^{18} \mathrm{O}_{\mathrm{p}}=15.0\right.$ to $\left.19.2 \% 0\right)$ document water compositions of $\mathbf{- 8 . 1}$ to $-6.1 \% 0$ and -7.7 to $-4.2 \%$, respectively, within the zonal range for formation-scale meteoric water at $34^{\circ} \mathrm{N}$ paleolatitude $\left(-7.1\right.$ to $-4.8 \%$ ) established by pedogenic carbonates $\left(\delta^{18} \mathrm{O}_{\mathrm{c}}=22.0\right.$ to $23.5 \% \mathrm{~V}$-SMOW). These data suggest that, like soil carbonates, turtle and crocodile phosphate isotopes can be used as proxies for meteoric water isotopic composition. Dinosaur $\delta^{18} \mathrm{O}_{\mathrm{p}}$ (sauropods: 19.7 to $21.9 \%$, ornithischians: 16.6 to $21.7 \%$, small theropods: 16.9 to $18.2 \%$, and large allosauroids: 19.1 to $20.3 \%$ ) values generally exceed those of semi-aquatic taxa. Using mass-balance equations for modern terrestrial animals adjusted for size and inferred dinosaur physiology, ingested water is calculated for the above dinosaur groups. On a member scale, when meteoric-water values are compared with calculated dinosaur drinking water, values are equal to or lighter than meteoric water for most herbivorous groups (as low as $-15.5 \%$ for ornithischians) and equal to or heavier than meteoric water for most carnivorous groups (as high as $\mathbf{- 2 . 0} \%$ for allosauroids). Changes in $\delta^{18} \mathrm{O}_{\text {meteoric water, }}$ $\delta^{18} \mathrm{O}_{\text {dinosaur ingested water, }}$ faunal assemblages, and sedimentology, from member to member, correlate to thrusting events of the Sevier Orogeny. High elevations in the orogeny attenuated the influences of Pacific moisture, causing rainshadow-induced aridity on the leeward foreland basin during upper Yellow Cat time, and hosted seasonal snow accumulation by the end of Ruby Ranch time, as suggested by ${ }^{18} \mathrm{O}$-enriched water (e.g., up to an average of $-2.0 \%$ from an allosauroid tooth) and extremely ${ }^{18} \mathrm{O}$-depleted water (e.g., $-\mathbf{1 5 . 5 \%}$ for ornithischians) in the Ruby Ranch Member. By Mussentuchit-time, delivery of the Western Interior Seaway-dominated moisture to the region, despite continued rise of the Sevier Mountains.
\end{abstract}

\section{INTRODUCTION}

The Cedar Mountain Formation (CMF), Utah, U.S.A., preserves some of the oldest terrestrial Cretaceous sediments in North America (Currie 1998, 2002; DeCelles and Coogan 2006; Kirkland and Madsen 2007) and records one of the highest Cretaceous temperatures and atmospheric $\mathrm{CO}_{2}$ concentrations prior to the Cenomanian-Turonian thermal maximum. At the same time, highlands to the west (Sevier Mountains) provided sediment to the CMF and likely also affected regional climate and precipitation patterns in east-central Utah. As is seen with the Himalayan orogen,

\footnotetext{
* Present Address: Department of Geosciences, University of Arkansas, 346 Arkansas Avenue, Fayetteville, Arkansas 72701, U.S.A.
}

tectonics can greatly affect climate at a regional or even global scale. Both regional (orogeny) and global $\left(\mathrm{CO}_{2}\right.$ and temperature) influences on climate can be deciphered using isotopic proxies for paleohydrology.

The hydrology of ancient ecosystems serves as a window into past climates, and oxygen isotopes are a useful measure of hydrologic change. Therefore, oxygen-isotope investigations of ancient ecosystems provide a valuable means of understanding past hydrology and climate. Oxygenisotope analyses of fossil invertebrates, vertebrates, and authigenic minerals have been used to decipher past precipitation rates and isotopic compositions, paleoelevation, paleo-migration, and paleoclimates (e.g., Koch 1998; Kohn and Cerling 2002; Ufnar et al. 2004; Kohn and Dettman 2007; Fricke et al. 2008, 2009; Suarez et al. 2009; Suarez et al. 2012). 


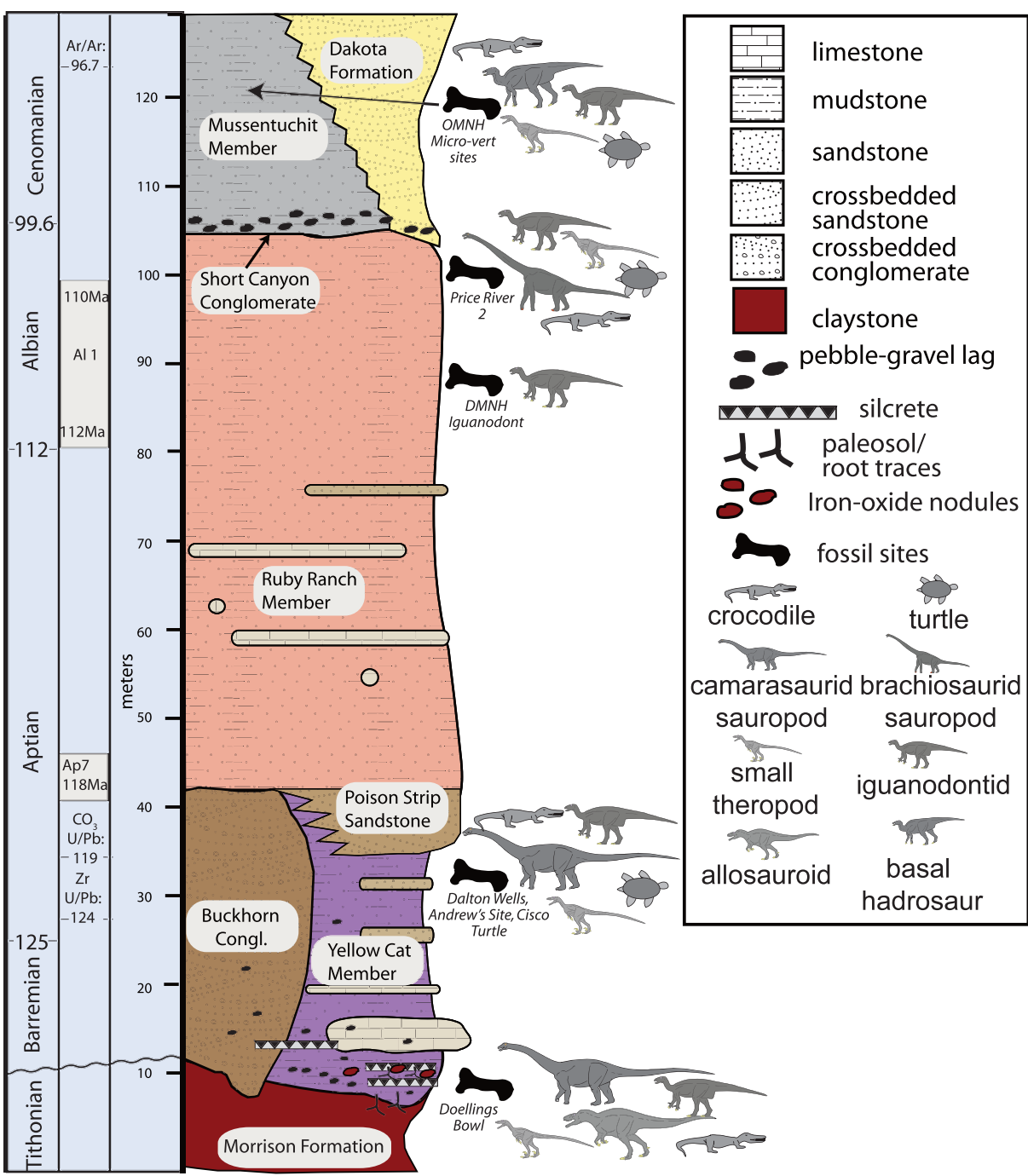

FIG. 1.- Relative Stratigraphy. Combined stratigraphy and relative location of sites in the Cedar Mountain Formation. Far left-hand column represents the Cretaceous stages and age boundaries to those stages; middle column presents published dates from either $\mathrm{U} / \mathrm{Pb}$ or $\mathrm{Ar} /$ Ar dating of detrital zircons, bentonites, or pedogenic carbonate. Gray bars in the column represent published carbon-isotope excursions identified by Ludvigson et al. (2010); right-hand column represents relative meters above the Morrison starting at the Buckhorn Conglomerate-Morrison boundary.
Here, we attempt to deconvolve the effects of changing tectonics (formation of the Nevadaplano Plateau during the Sevier Orogeny), sea level (incursion of the Western Interior Seaway), and climate $\left(\mathrm{CO}_{2}\right.$ and temperature) on the regional water sources of the Cedar Mountain Formation ecosystem. We inferred the isotopic compositions of meteoric water and ingested water from compositions of pedogenic calcite and representative vertebrate fauna (turtles, crocodiles, and dinosaurs) respectively. Although previous researchers have hesitated to estimate the isotopic composition of ingested water of extinct taxa, reasonable estimates are possible by taking into account the primary factors (humidity, body temperature, ingested water) that affect $\delta^{18} \mathrm{O}_{\mathrm{p}}$ of largebodied, terrestrial animals that live today as a modern analogue-see Discussion section (Kohn 1996). These compositions permit refined interpretations of the effects of Sevier Mountain uplift and the incursion of the Western Interior Seaway (WIS) on local climate in a warming Cretaceous world.

\section{GEOLOGIC SETTING AND MATERIALS}

\section{Stratigraphy and Paleontology}

The Cedar Mountain Formation (CMF) was first designated (Stokes 1949) as a drab mudstone between the Jurassic Morrison Formation and the middle Cretaceous Dakota Formation (Fig. 1). The CMF is informally separated into five members - the Buckhorn Conglomerate, the Yellow Cat Member, the Poison Strip Sandstone, the Ruby Ranch Member, and the Mussentuchit Member - and likely spans the Barremian $(\sim 130 \mathrm{Ma})$ through early Cenomanian $(\sim 96 \mathrm{Ma})$ ages (Kirkland and Madsen 2007).

The Buckhorn Conglomerate was deposited in northeast-flowing rivers that cut into the Morrison Formation and is made up of fossiliferous Paleozoic marine carbonate clasts reworked from uplifted Sevier highlands in Nevada (Currie 2002; DeCelles and Coogan 2006; Kirkland and Madsen 2007). It crops out predominantly on the western side of the San Rafael Swell and is roughly equivalent to the Yellow Cat Member and the Poison Strip Sandstone in some places. No samples were analyzed from the Buckhorn Conglomerate as few vertebrate remains have been discovered in the conglomerate.

Until recently, the Yellow Cat Member was defined by poorly sorted drab green and purple, carbonate-rich, pebbly siltstones above either the Buckhorn Conglomerate or the Morrison Formation and below the Poison Strip Sandstone (Kirkland and Madsen 2007). Aubrey (1998) and Greenhalgh (2007) proposed that a carbonate-rich paleosol (calcrete) that overlies and pedogenically alters the Buckhorn Conglomerate and/or the Morrison Formation represents a major unconformity between the Jurassic and Cretaceous and marks the lower contact of the Yellow Cat Member. However, recent finds of Cretaceous-age dinosaurs below this contact suggests that yet older Cretaceous sediments are preserved in the CMF outcrops of Utah (Kirkland and Madsen 2007). Thus, we refer to 


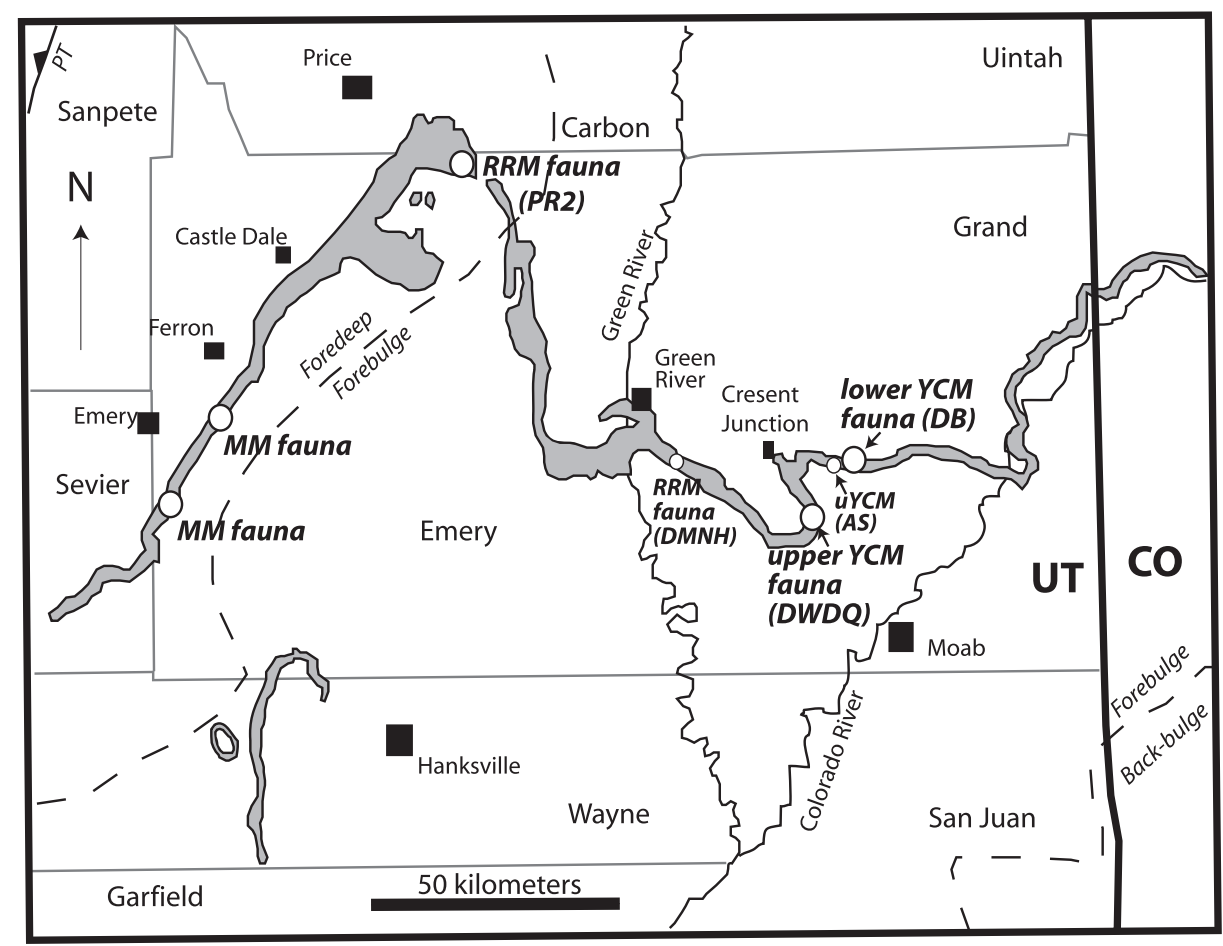

FIg. 2.-Map of Cedar Mountain Formation outcrop (gray shaded area). County boundaries are in gray. Dashed lines represent boundaries between the paleo-foredeep, forebulge, and backbulge during Albian time (Currie 2002). The location of the Pavant Thrust front (PVT) is located in the far northwest. Fossil localities are in bold italics. Members: IYCM, lower Yellow Cat Member; uYCM, upper YCM; RRM, Ruby Ranch Member; MM, Mussentuchit Member. Sites: DB, Doelling's Bowl; DWDQ, Dalton Wells Dinosaur Quarry; PR2, Price River 2; AS, Andrew's Site; DMNH, location of iguanodontid jaw from the Denver Museum of Nature and Science. rocks below vs. above the contact as the "lower" vs. "upper" Yellow Cat Members.

The lower Yellow Cat Member is represented by green pebbly siltstone and mudstone with abundant silicified rootlets, tree stumps, iron-oxide nodules, and silcretes that are interpreted as mature soils that are well exposed in the Doelling's Bowl area (Kirkland and Madsen 2007; Fig. 2). It likely represents sedimentation between $\sim 149$ to $\sim 124 \mathrm{Ma}$, bracketed by $\mathrm{U} / \mathrm{Pb}$ zircon dates from a Morrison Formation bentonite (Kowallis et al. 2007) and a detrital-zircon date for the upper Yellow Cat Member near Moab, UT (Britt et al. 2007), respectively. Unfortunately, calcitic carbonate nodules are not common in the lower Yellow Cat Member for comparison to water $\delta^{18} \mathrm{O}$ calculated from the vertebrate phosphate.

We sampled semi-aquatic taxa (crocodile) and terrestrial taxa: basal macronaran sauropods, iguanodontids, allosauroids, and smaller theropods. None of the teeth sampled could be identified below the family level, since dinosaur teeth are notoriously uninformative for species- or even genus-specific identification. A list of genera and as yet undescribed specimens are listed in archived Table A1 (see Supplemental Material).

The upper Yellow Cat Member is a poorly sorted pebbly siltstone with abundant pedogenic carbonate, spring carbonate, and palustrine carbonate with interbedded small-channel sandstone and is likely no younger than $\sim 119.4 \pm 2.6 \mathrm{Ma}$ based on $\mathrm{U} / \mathrm{Pb}$ date from carbonate at the base of the overlying Poison Strip Sandstone (Ludvigson et al. 2010). An increase in pedogenic carbonates and poorly sorted sediments relative to the lower Yellow Cat Member suggests drier conditions. These features are expected for the foreland-basin system of the Sevier Mountains, where denuded landforms would be unstable and experience high erosion rates (Eberth et al. 2006; Elliott et al. 2007). The upper Yellow Cat Member has produced numerous significant vertebrate fossils of both European and Asian affinity. The majority of the upper Yellow Cat Member fauna sampled are from the Dalton Wells Dinosaur Quarry (DWDQ) (Eberth et al. 2006; Britt et al. 2009). The site is $\sim 6-10 \mathrm{~m}$ below the Poison Strip Sandstone in a poorly sorted, carbonate-rich, pebbly siltstone. All taxa sampled from the DWDQ are terrestrial and include sauropod (basal macronaran or camarasaurid) teeth, a very large iguanodontid jaw with teeth, and Utahraptor teeth (Table A1). Several turtle shell fragments from near Cisco, Utah, were sampled within $10 \mathrm{~m}$ of the overlying Poison Strip Sandstone. A large meso-eusuchian crocodile scute from a site (Andrew's Site) just off Yellow Cat Road, south of Crescent Junction, Utah, was also sampled. Both crocodile and turtle remains correlate with DWDQ on a scale of $\sim 10^{5}$ to $10^{6}$ years. Considering that uplift of the Sevier Mountains occurred over an $\sim 20 \mathrm{Ma}$ interval, grouping of these taxa is appropriate for tracking long-term climatic and orogenic processes.

The Poison Strip Sandstone is a thick, ledge-forming fluvial to lacustrine beach sandstone. It is light tan to white, medium- to coarsegrained, and contains cross-bedded to planar-bedded sandstone. Ludvigson et al. (2010) radiometrically dated a palustrine carbonate (U/Pb from calcite) from the base of the Poison Strip Sandstone at $\sim 119.4 \pm$ 2.6 Ma. This age is consistent with the detrital-zircon age of the upper Yellow Cat Member of $124 \mathrm{Ma}$ (Britt et al. 2007). The Poison Strip Sandstone is not included in the study, because too few teeth were available.

The Ruby Ranch Member is a complex of reddish and gray mudstones and carbonate-nodule-bearing mudstones. Irregularly shaped carbonate nodules reach tens of centimeters in diameter. In places, carbonate nodules form thick carbonate horizons of intergrown spheroidal to cylindroidal carbonate layers or calcretes (Al-Suwaidi 2007). Some calcretes formed in palustrine to lacustrine environments (Shapiro et al. 2009), whereas others resulted from vadose processes (Al-Suwaidi 2007). Dolomite is common in paleosols as well as dolomitic layers in lacustrine deposits and indicates xeric conditions. Only micritic pedogenic calcite analyzed under thin section from the study of Al-Suwaidi (2007) and Ludvigson et al. (2010) were used in this study. Recently, a carbonisotope chemostratigraphic study by Ludvigson et al. (2010) identified several distinct carbon-isotope excursions such as carbon-isotope feature Ap7 (Herrle et al. 2004) at the base of the Ruby Ranch Member and the All C-isotope feature in the upper Ruby Ranch, bracketing the age of the Ruby Ranch Member from the early-mid Aptian ( $118 \mathrm{Ma})$ to the end 
of the Albian ( 100.5 Ma). The fauna sampled for this study are from the top of a very thick section of the Ruby Ranch Member. The Price River 2 (PR2) samples include crocodile teeth and turtle shell fragments (both Naomichelys sp. and unidentified), several teeth from a "slendertoothed" brachiosaurid, Acrocanthosaurus teeth (allosauroid), and small dromaeosaurid teeth. To compare with iguanodontids from the lower and upper Yellow Cat Member, a juvenile iguanodontid jaw and teeth (possibly related to Tennontosaurus) were analyzed from the middle of the Ruby Ranch Member southeast of Green River.

The Mussentuchit Member crops out primarily on the western limb of the San Rafael Swell (Fig. 2) and rests unconformably on a zone of chert and quartzite pebbles (Kirkland and Madsen 2007; Doelling and Kuhne 2013). Several ash ages range from $98.37 \pm 0.07 \mathrm{Ma}$ (Cifelli et al. 1999) to $96.7 \pm 0.5 \mathrm{Ma}$ (Garrison et al. 2007). Palynologic studies of correlative strata (Oboh-Ikuenobe et al. 2007) and geochronology of the Mussentuchit suggest deposition from the end of the Albian to the basal Cenomanian (Sprinkle et al. 2012). Most of the Mussentuchit Member consists of interbedded gray smectitic mudstones, lignitic mudstones, siltstones, and occasional fine-grained sandstones. The upper part of this member is interbedded with or truncated by the overlying Dakota Formation. Carbonate nodules are less common than in the underlying Ruby Ranch Member. Micro-vertebrates dominate vertebrate remains and represent one of the richest terrestrial faunas described from the early Cretaceous (Cifelli et al. 1999). Samples used for this study were originally analyzed for an isotopic study of the Mussentuchit Member fauna and paleohydrology (Suarez et al. 2012) and were averaged from seven sites spanning $\sim 15 \mathrm{~m}$. Specimens include teeth and osteoderms from crocodiles (including Goniopholidae, Atoposaruidae, and Bernissartia sp.), turtle shell fragments (including Naomichelys sp., Glyptops sp., and Trionychidae), teeth from the advanced iguanodontid Eolambia caroljonesa (Kirkland 1998), polocanthine ankylosaurs, teeth from an undescribed species of basal hypsilophodont, and dromaeosaurid theropod teeth. A species list of taxa that have been found in the member can be found in Table A1.

For this study, we have created two herbivore categories, sauropods (which include the brachiosaurid, camarasaurid, and macronaran sauropods) and ornithischians (which include the iguanodontidsincluding unnamed species, hypsilophodont, Eolambia, and polocanthine ankylosaur teeth). We created two groups of carnivorous dinosaur, the large carnivorous dinosaurs (which include large allosauroid-like teeth) and a small theropod dinosaur-tooth category (which primarily includes small dromaeosaurid teeth). These categories are created because there are not enough samples that are identifiable below the family level to make meaningful comparisons from stratigraphic unit to stratigraphic unit. Although we recognize that there can be significant interspecies variability, these groupings are viable when comparing climate change on million-year time scales. Also, these groupings are along ecological lines (e.g., carnivores versus herbivores, large carnivores versus small carnivores, saurischian herbivores versus ornithischian herbivores). Since isotopic compositions of vertebrates are controlled primarily by physiology and ecology (e.g., habitat that controls humidity, temperature, etc.), these groups are valid.

\section{Tectonic and Climatic Setting}

The CMF sediments were sourced from highlands to the west, which were eroded from the Sevier Fold and Thrust Belt (SFTB) - a segment of the larger Cordilleran retroarc fold-and-thrust belt-that formed during late Mesozoic to early Cenozoic times (DeCelles and Coogan 2006). The SFTB forebulge migrated to the east so that the Yellow Cat and lower Ruby Ranch members were deposited between the distal foredeep and proximal backbulge of the 110-145 Ma Canyon Range Thrust, the upper Ruby Ranch Member was deposited in the distal foredeep to forebulge area of the 86-110 Ma Pavant Thrust, and the Mussentuchit Member was deposited in the foredeep of the Pavant Thrust. Regional elevations are interpreted to have increased by $\sim 1.6 \mathrm{~km}$ by the end of the Canyon Range thrust event (middle of the Ruby Ranch Member), and at least $2.8 \mathrm{~km}$ in western Utah by the end of the Pavant thrust event (DeCelles and Coogan 2006). By the Late Cretaceous, the SFTB formed an Andean-style fold-and-thrust belt with a high-elevation, low-relief hinterland plateau (Currie 2002; DeCelles and Coogan 2006; Snell et al. 2013) - the "Nevadaplano"- analogous to the Altiplano in the central Andes Mountains today (DeCelles and Coogan 2006).

Regional climate and paleohydrology were likely affected by these orogenic events because the rise of the Sevier Mountains must have impeded eastward-moving moisture transported by the paleo-westerlies (Poulsen et al. 2007). One of the goals of this study was to determine the extent to which the Sevier Orogeny and development of "Nevadaplano" affected paleohydrology, by analyzing the isotopic compositions of pedogenic calcite and vertebrate phosphates.

Globally, the Aptian to Albian experienced warming towards a thermal maximum in the Cenomanian-Turonian. Significant perturbations to the global carbon cycle are indicated by several events of widespread organic matter deposition, called oceanic anoxic events (OAEs), and are associated with variations in carbon isotope chemostratigraphy in marine and terrestrial sequences (Menegatti et al. 1998; Grocke et al. 1999; Jenkyns 2003; Ludvigson et al. 2010). During CMF deposition ( 125 to $96 \mathrm{Ma}$ ), both global-warming and global-cooling trends have been documented in marine and nearshore deposits. A decrease in marine carbonate $\delta^{18} \mathrm{O}$ and organic-matter $\delta^{13} \mathrm{C}$ just prior to OAEla (end of the early Aptian, $\sim 125 \mathrm{Ma}$ ) is ascribed to increased greenhouse gases and global warming (Bellanca et al. 2002). A subsequent increase in carbonate $\delta^{18} \mathrm{O}$ is interpreted as cooling due to increased burial of organic carbon. $\mathrm{TEX}_{86}$ paleothermometry documents similar trends (Dumitrescu et al. 2006). Pedogenic carbonate isotopes during the Aptian-Albian thermal maximum (White et al. 2001; Ufnar et al. 2002, 2004; Suarez et al. 2009) suggest that increased temperature led to an intensification of the global hydrologic cycle. Increased rainout intensity explains increased isotopic depletion of meteoric groundwaters seen along the eastern margin of the WIS (White et al. 2001), in the British Wealden (Robinson et al. 2010), and at high latitudes (Suarez et al. 2011). Alternatively, extreme depletion of pedogenic carbonates at high latitudes may have resulted from local orogenic effects (Poulsen et al. 2007). The present study further illustrates the dynamics of the hydrologic cycle in a tectonically active setting.

\section{CONTROLS ON O-ISOTOPE COMPOSITIONS OF CONTINENTAL VERTEBRATES}

The isotopic composition of continental vertebrates is controlled primarily by ingested surface water and relative humidity, especially for non-aquatic and semi-aquatic taxa (Table 1). Offsets across the landscape in water sources can be recorded in bioapatites of the taxa that live in or consume these various water sources. Turtles precipitate their carapace under a narrow range of body temperatures, allowing linear regressions between the isotopic composition of modern water $\left(\delta^{18} \mathrm{O}_{\mathrm{w}}\right)$ and the isotopic composition of modern turtle phosphate $\left(\delta^{18} \mathrm{O}_{\mathrm{p}}\right)$ as a proxy for ancient water $\delta^{18} \mathrm{O}$ (Barrick et al. 1999; Coulson et al. 2008). Analysis of turtle-bone $\delta^{18} \mathrm{O}_{\mathrm{p}}$ suggests that it records meteoric water (Barrick et al. 1999; Coulson et al. 2008). This can be compared to other meteoric-water proxies, such as pedogenic carbonate. Pedogenic carbonates are known to record average or slightly ${ }^{18} \mathrm{O}$-enriched end members of local meteoric water (Cerling and Quade 1993; Breecker et al. 2009; Suarez et al. 2009), so $\delta^{18} \mathrm{O}_{\mathrm{w}}$ calculated from turtle carapace can be compared with pedogenic calcite to determine the degree of evaporative enrichment of meteoric water, or potential influx of orographically ${ }^{18} \mathrm{O}$-depleted water into the rivers in which turtles lived. Crocodiles have living habits similar to those of turtles and have been known to record meteoric water, although their 
TABLE 1.-Factors controlling vertebrate $\delta^{18} O_{p}$.

\begin{tabular}{lll}
\hline \hline \multicolumn{1}{c}{ Organism } & \multicolumn{1}{c}{ Factors Controlling $\delta^{18} \mathrm{O}_{\mathrm{p}}$} & \multicolumn{1}{c}{ Information Given } \\
\hline Turtle carapace: & Drinking water & Meteoric water \\
Crocodile teeth: & Drinking water & Meteoric water \\
Fish scales, teeth: & Living water, temperature & Water temperature, with known $\delta^{18} \mathrm{O}_{\mathrm{w}}$ values, or $\delta^{18} \mathrm{O}_{\mathrm{w}}$ with known temperature \\
Herbivorous dinosaur teeth: & Drinking water, relative humidity, plant water & Varies: meteoric, stream, plant, ponds, lake \\
Carnivorous dinosaur teeth: & Drinking water, relative humidity & Varies: meteoric water, streams, ponds, lake \\
Herbivorous mammals teeth: & Drinking water, relative humidity, plant water & Varies: meteoric water, steam, plant, ponds, lake \\
Carnivorous mammal teeth: & Drinking water, relative humidity & Varies: meteoric, streams, ponds, lake \\
\hline
\end{tabular}

larger size may require more active cooling through gaping (opening the mouth for evaporative cooling). Therefore, lower humidity and warm conditions may act to enrich their body water in ${ }^{18} \mathrm{O}$ relative to turtles (Markwick 1998; Pough et al. 2002). All large-bodied thermoregulating terrestrial animals (non-aquatic) have similar relationships between ingested surface water and $\delta^{18} \mathrm{O}$ of tooth phosphate (Kohn 1996), with the dominant control on $\delta^{18} \mathrm{O}_{\mathrm{p}}$ being surface water and relative humidity. Depending on the relative humidity, body water of terrestrial animals tends to be enriched compared with drinking water due to water loss by panting or transcutaneous water loss (evaporative enrichment). Herbivores tend to be enriched relative to carnivores because of the consumption of isotopically enriched plant leaves in arid climates. Leaf water is strongly ${ }^{18} \mathrm{O}$-enriched compared to meteoric water due to evaporation during photosynthesis, with higher $\delta^{18} \mathrm{O}$ values at lower relatively humidity (Farquhar et al. 1989; Flanagan and Ehleringer 1991).

Source water can sometimes be significantly depleted relative to local meteoric (rain) water if animals consume a significant portion of water that is sourced from high elevations, where precipitation is depleted due to orographic rainout, cooler temperatures, and/or melting snow (e.g.,
Dettman and Lohmann 2000; Dutton et al. 2005). Thus comparison of vertebrate bioapatite and pedogenic carbonate isotope compositions in the CMF can be used to identify regional climatic effects of the Sevier Orogeny in an overall greenhouse world.

\section{METHODS}

Samples (Table 2) were provided by the Oklahoma Museum of Natural History $(\mathrm{OMNH})$, the Utah Museum of Natural History, $(\mathrm{UMNH})$, the College of Eastern Utah Museum (CEUM), Denver Museum of Nature and Science (DMNH), and Brigham Young University Museum of Vertebrate Paleontology (BYUVP). When possible, at least ten individuals per taxonomic group or at least ten isotopic measurements per taxonomic group per site were obtained, which exceeds the recommended $3-5$ serially sampled teeth per taxon per stratigraphic level required to determine the seasonal variability and range in $\delta^{18} \mathrm{O}_{\mathrm{p}}$, along with the minimum number required to evaluate the average standard deviation of $\delta^{18} \mathrm{O}_{\text {enamel }}$ (Clementz and Koch 2001; Levin et al. 2006; Kohn and Dettman 2007).

TABLE 2.-Oxygen analysis of phosphate, calcite, and water relative to V-SMOW.

\begin{tabular}{|c|c|c|c|c|c|c|c|c|}
\hline & Taxa & $N_{\text {specimen }}$ & $N_{\text {samples }}$ & Min,\%o & Max,\%o & $\delta^{18} O_{p} \pm 1 \sigma, \%$ & $\delta^{18} O_{w} \pm 1 \sigma, \%$ & $\begin{array}{c}\text { Global } \delta^{18} O_{w} \\
\text { (Kohn and Cerling 2002), \%o }\end{array}$ \\
\hline \multirow[t]{19}{*}{ Fauna } & \multicolumn{8}{|c|}{ Mussentuchit: 19 to $4 \mathrm{~m}$ below Dakota } \\
\hline & Crocodilia & 59 & 103 & 14.4 & 19.5 & $16.8 \pm 0.9$ & $-6.2 \pm 0.8$ & \\
\hline & Calcite & 2 & 5 & 19.91 & 24.27 & $23.30 \pm 1.9$ & $-5.8 \pm 1.8$ & \\
\hline & Avg. Herbivores & 42 & 86 & 14.0 & 18.6 & $16.6 \pm 0.9$ & $-9.3 \pm 1.4$ & -9.3 \\
\hline & Theropoda & 28 & 42 & 15.3 & 20.0 & $17.5 \pm 1.4$ & $-4.6 \pm 2.0$ & -8.3 \\
\hline & Turtle & 3 & 18 & 13.4 & 16.1 & $14.9 \pm 0.8$ & $-7.3 \pm 0.8$ & \\
\hline & Calcite & 3 & 14 & 22.59 & 24.59 & $23.52 \pm 0.61$ & $-5.6 \pm 0.6$ & \\
\hline & Sauropoda & 2 & 25 & 16.6 & 22.2 & $19.7 \pm 1.6$ & $-9.0 \pm 2.3$ & -5.9 \\
\hline & Iguanodontid & 6 & 13 & 14.4 & 15.8 & $15.1 \pm 0.4$ & $-15.5 \pm 0.6$ & -11.0 \\
\hline & Allosauroid & 4 & 25 & 17.8 & 24.9 & $20.5 \pm 2.4$ & $-2.0 \pm 3.3$ & -5.0 \\
\hline & Small Theropod & 4 & 5 & 16.7 & 21.4 & $18.2 \pm 1.9$ & $-5.3 \pm 2.6$ & -7.6 \\
\hline & Iguanodontid & 3 & 6 & 20.5 & 22.2 & $21.7 \pm 0.6$ & $-6.2 \pm 0.9$ & -3.7 \\
\hline & Theropoda: Utahraptor & 4 & 19 & 15.6 & 19.1 & $18.1 \pm 0.9$ & $-5.4 \pm 1.3$ & -7.7 \\
\hline & \multicolumn{8}{|c|}{ Lower Yellow Cat: $30 \mathrm{~m}$ below Poison Strip SS ( $8 \mathrm{~m}$ above Morrison) } \\
\hline & Crocodilia & 2 & 9 & 18.5 & 19.9 & $19.2 \pm 0.5$ & $-4.2 \pm 0.4$ & \\
\hline & Sauropoda & 3 & 44 & 17.0 & 24.4 & $21.9 \pm 2.8$ & $-3.4 \pm 3.9$ & -3.4 \\
\hline & Iguanodontid & 8 & 33 & 13.8 & 21.3 & $17.7 \pm 2.3$ & $-9.3 \pm 3.3$ & -8.1 \\
\hline & Allosauroid & 1 & 29 & 17.7 & 20.3 & $19.1 \pm 1.7$ & $-2.9 \pm 1.0$ & -6.6 \\
\hline & Small theropod & 3 & 22 & 14.7 & 20.2 & $16.9 \pm 1.8$ & $-6.1 \pm 2.5$ & -9.0 \\
\hline
\end{tabular}

* based on converted crocodile scute to crocodile tooth: crocodile scute $+1.3 \%$. 
Samples were drilled for enamel by hand using a dental drill, producing $200-500 \mu \mathrm{g}$ of powder. Larger teeth were analyzed every $1-2 \mathrm{~mm}$ serially from base to apex of the tooth. For teeth smaller than $\sim 5 \mathrm{~mm}$ (from apex to base), one to two samples were drilled for powder. Like other modern archosaurs, dinosaur teeth grew continuously and at a formation rate that ranges from $\sim 130$ days for infant Maiasaurus to a maximum of $\sim 900$ days for adult Tyrannosaurus (Erickson 1996). Thus, the amount of time represented in larger teeth maybe a complete year or more, while smaller teeth represent approximately 4-5 months within the year. Significant care was taken to avoid sampling dentine, since it is more prone to diagenetic exchange of oxygen isotopes than enamel (Kolodny et al. 1996).

Silver phosphate was precipitated following the method of O'Neil et al. (1994), modified by Bassett et al. (2007) and analyzed at the Keck Paleoenvironmental and Environmental Stable Isotope Laboratory (KPESIL) at the University of Kansas, Department of Geology, on a high-temperature conversion elemental analyzer (TC/EA) connected to a ThermoFinnigan MAT 253 continuous-flow mass spectrometer. Phosphate oxygen $\left(\delta^{18} \mathrm{O}_{\mathrm{p}}\right)$ is reported in parts per thousand (\%) relative to $\mathrm{V}$ SMOW using standard $\delta$ notation. Precision was monitored via analysis of 2-3 NIST 120c samples analyzed per run, with a total of greater than 100 individual measurements of NIST 120c samples over the dates of analysis. The average measured value of NIST $120 \mathrm{c}$ was $22.5 \pm 0.30 \%$ V-SMOW one standard deviation.

For turtles, isotopic compositions of ingested water or the water in which they lived $\left(\delta^{18} \mathrm{O}_{w}\right)$ were calculated from a modern freshwater turtlewater equation (Barrick et al. 1999):

$$
\delta^{18} \mathrm{O}_{\mathrm{w}}=1.01 \delta^{8} \mathrm{O}_{\mathrm{p}(\text { turtle })}-22.3
$$

A newer equation that includes sea turtles (Coulsen et al. 2008), produces nearly identical results.

For crocodilian material, local water compositions were calculated from a modern crocodilian calibration (Amiot et al. 2007) modified by $0.8 \%$ for differences in standards calibrations:

$$
\delta^{18} \mathrm{O}_{\mathrm{w}}=0.82 \delta^{18} \mathrm{O}_{\mathrm{p} \text { (crocodile) }}-19.93
$$

The original equation was generated using data calibrated using an NIST 120c value of 21.7\% (VSMOW; Amiot, personal communication 2011). We did not use NIST 120c as a calibration standard rather as a quality control value, because NIST 120c is not an official stable-isotope standard for $\mathrm{O}$ isotopes of phosphate (yet a commonly used isotope standard) and because NIST 120c shows large inter-laboratory variability (e.g., 21.7 to 22.6; Vennemann et al. 2002; Lécuyer 2004). The large range of values for NIST $120 \mathrm{c}$ has been an ongoing issue in the isotope community. Because NIST 120c analyzed at KPESIL was consistent at $22.5 \pm 0.30 \%$, we subtracted $0.8 \%$ from the original calibration (Amiot et al. 2007).

Crocodile material from the upper Yellow Cat Member only includes crocodile scutes, which are known to be ${ }^{18} \mathrm{O}$-depleted by $1.1-1.5 \%$ relative to tooth enamel from the same individual (Lécuyer et al. 2003; Billon-Bruyat et al. 2005; Suarez et al 2012). Because the relationship between ingested water and phosphate was based on tooth phosphate (Amiot et al. 2007), enamel values were estimated from scute composition by adding $1.3 \%$.

Dinosaur ingested water was estimated using modified biological parameters for herbivorous birds as presented by Kohn (1996). Kohn (1996) created a mass-balance equation accounting for input O moles and isotopic composition and output $\mathrm{O}$ moles and isotopic composition and modifies each for different animal physiologies. For herbivorous dinosaurs, the Kohn (1996) bird equation was modified to account for a sustained body temperature of $37^{\circ} \mathrm{C}$ versus $38^{\circ} \mathrm{C}$ (Amiot et al. 2006; Eagle et al. 2011), a much larger body size ( $200 \mathrm{~kg}$ versus $0.15 \mathrm{~kg}$ for herbivorous birds in the Kohn model; this alters the food input requirements and respiratory $\mathrm{O}_{2}$ requirements as well as output amounts), slightly lower digestibility for food from 0.9 to 0.7 (coniferous forest food versus deciduous leaves), and a body-size-scaled estimate of water loss from skin (which was otherwise fixed for birds; Table A2). Because, the original theoretical model implicitly assumed analysis via $\mathrm{BiPO}_{4}$, rather than $\mathrm{Ag}_{3} \mathrm{PO}_{4}$ and because oxygen-isotope compositions generated via $\mathrm{BiPO}_{4}$ analysis are $\sim 1.0 \%$ lower than that generated via $\mathrm{Ag}_{3} \mathrm{PO}_{4}$ (O'Neil et al. 1994; Chenery et al. 2010), we increased the fractionation between phosphate and body water by $1 \%$ (Table A2). These modifications result in the following equations for ingested water by herbivorous dinosaurs:

$$
\delta^{18} \mathrm{O}_{\mathrm{w}}=1.41 \delta^{18} \mathrm{O}_{\mathrm{p}}+19.6 h-46.0
$$

and by carnivorous dinosaurs:

$$
\delta^{18} \mathrm{O}_{\mathrm{w}}=1.43 \delta^{18} \mathrm{O}_{\mathrm{p}}+7.9 h-35.0
$$

where $\delta^{18} \mathrm{O}_{\mathrm{p}}=$ the isotopic composition of phosphate oxygen and $h=$ relative humidity. Sensitivity analysis for numerous groups implies uncertainties of c. $2 \%$ in predicted $\delta^{18} \mathrm{O}_{\mathrm{p}}$ (Kohn 1996), which propagates to $\sim \pm 3 \%$ uncertainty in $\delta^{18} \mathrm{O}_{\mathrm{w}}$. Models for herbivores predict modern data within error, but global datasets are extremely carnivore-sparse, so the accuracy of Eq. 5 is as yet unknown.

Relative humidity for the upper Yellow Cat Member and the Ruby Ranch Member was estimated at $47 \%$ based on modeling using empirically derived meteoric-water values from pedogenic carbonates sampled at a range of latitudes (Suarez et al. 2011). For the Mussentuchit Member, mammal-tooth $\delta^{18} \mathrm{O}$ suggests an average relative humidity of $68 \%$ (Suarez et al. 2012). For the lower Yellow Cat Member, considering the lack of pedogenic carbonate and the presence of paleosols with abundant iron oxide nodules and redoximorphic features, humidity must have been greater than $47 \%$, and we estimate it at $\sim 60 \%$, to fall between the Mussentuchit values and those of the upper Yellow Cat and Ruby Ranch members.

A more simplistic approach for estimating $\delta^{18} \mathrm{O}_{\mathrm{w}}$ is based on the $\delta^{18} \mathrm{O}_{\mathrm{p}}-$ $\delta^{18} \mathrm{O}_{\mathrm{w}}$ relationship derived from the global dataset for water-dependent mammals (Kohn and Cerling 2002). We adjusted the $\delta^{18} \mathrm{O}_{\mathrm{p}}{ }^{18} \mathrm{O}_{\mathrm{w}}$ relationship upward by $2 \%$ to account for standardization differences (see above) and isotopic offsets between modern birds vs. mammals (Kohn 1996):

$$
\delta^{18} \mathrm{O}_{\mathrm{w}}=1.11 \delta^{18} \mathrm{O}_{\mathrm{p}}-27.8
$$

Dinosaur phosphate $\mathrm{O}$ values are used in equation 5 and can be compared to Equations 3 and 4 only at moderate relative humidity from which most global data derive. Animals in arid environments have increasingly high $\delta^{18} \mathrm{O}_{\mathrm{p}}$ values relative to local water, so estimated $\delta^{18} \mathrm{O}_{\mathrm{w}}$ using Eq. 5 in settings drier than $\sim 60 \%$ relative humidity can be several permil too high.

Pedogenic calcite data were mostly compiled from previous studies of the Ruby Ranch Member (Al-Suwaidi 2007; Suarez et al. 2011). We also analyzed pedogenic calcite from the upper Yellow Cat and Ruby Ranch members. Samples were micro-drilled for 30-50 $\mu \mathrm{g}$ of carbonate, vacuum roasted at $200^{\circ} \mathrm{C}$ for 2 hours, and analyzed at $70^{\circ} \mathrm{C}$ in $100 \%$ phosphoric acid on a KIEL III carbonate sampling device connected to a ThermoFinnigan MAT 253 dual-inlet IRMS housed at the KPESIL in the Department of Geology, University of Kansas. Samples are reported relative to V-PDB but were converted to $\mathrm{V}-\mathrm{SMOW}$ to compare with phosphate oxygen analyses. At least two samples of NBS-18 and 19 each were analyzed per run with regular test runs of NBS-18 and 19 totaling well over 100 samples during the duration of analyses and resulted in precision better than $0.07 \%$ and $0.03 \%$ respectively. Samples from the 
Ruby Ranch Member and the upper Yellow Cat Member were carefully inspected petrographically, and samples of all carbonate phases were analyzed to be sure to differentiate primary micritic calcite that precipitated from meteoric water from sparry calcite that precipitated from burial fluids (Al-Suwaidi 2007; Suarez et al. 2009; Ludvigson et al. 2010). For the micrite component, several samples show meteoric calcite lines (invariant $\mathrm{O}$-isotope composition and variable $\mathrm{C}$-isotope composition) and positive linear covariant trends between $\mathrm{O}$ and $\mathrm{C}$ isotope compositions typical of modern soil carbonates, suggesting original carbonate material.

Meteoric-water compositions (reported relative to V-SMOW) for these calcites were calculated at an estimated mean annual temperature (MAT) of $22.7^{\circ} \mathrm{C}$ derived from leaf physiognomy (Wolfe and Upchurch 1987; Spicer and Corfield 1992). This value is used because it is independent of stable isotopes or modeled data. The $\delta^{18} \mathrm{O}_{\mathrm{w}}$ estimated from calcite is then

$$
\delta^{18} \mathrm{O}_{\mathrm{w}}=\left(\left(\delta^{18} \mathrm{O}_{\mathrm{c}}+10^{3}\right) / \alpha\right)-10^{3}
$$

where $\alpha$ is the calcite-water fractionation factor at $22.7^{\circ} \mathrm{C}(\alpha=1.0923)$ (O’Neil et al. 1969) The O’Neil (1969) fractionation factor (and not other more recent fractionation factors) was used to compare to $\delta^{18} \mathrm{O}_{\mathrm{w}}$ values calculated using the same fractionation factor by Ludvigson et al. (2010) and Suarez et al. (2011).

\section{Selection of Samples: Primary vs. Diagenetic Biogenic Isotope Signals}

The successful use of isotopic proxies in paleoecology and paleoclimatology studies requires that biogenic signals are retained in fossils as old as millions to hundreds of millions of years (Koch et al. 1989; Barrick et al. 1996; Kolodny et al. 1996; Sharp et al. 2000; Kohn and Cerling 2002). Our data set meets numerous proposed criteria for the retention of biogenic compositions (Koch et al. 1989; Kolodny et al. 1996; Kohn and Cerling 2002). First, we emphasize isotopes of the $\mathrm{PO}_{4}$ component of enamel. Phosphate oxygen is more resistant to diagenesis because of greater oxygen bond strengths than other components (e.g., $\mathrm{CO}_{3}$ ), and enamel is more resistant because of large crystal sizes (up to two orders of magnitude greater than bone) and low organic content, reducing crystallite reactivity with diagenetic pore waters (e.g., Kohn and Cerling 2002; Kohn and Law 2006). Systematic differences in isotopic compositions among taxa of different physiologies (e.g., coexisting turtles versus sauropods at all sites) further suggest preservation of original biogenic isotopic compositions. Diagenetic overprinting should either homogenize values among taxa (for a single diagenetic episode) or yield highly variable and taxonomically nonsystematic values (for multiple diagenetic episodes). Systematic zoning in longer teeth, including compositional reversals, is also inconsistent with diagenetic overprinting. Last, measured compositions differ considerably from pedogenic calcite-based predictions. For example, at $20-25^{\circ} \mathrm{C}$, soil water compositions of c. $-6 \%$ imply $\delta^{18} \mathrm{O}_{\mathrm{p}} \geq 22 \%$ (calibration of Lécuyer et al. 1996, corrected for differences in standards), whereas few values are so high for any group, and turtle and crocodile bone $\delta^{18} \mathrm{O}$ values are 2.5 to $9 \%$ lower.

\section{RESULTS}

The isotopic data (Table 2, Fig. 3) illustrate several important trends over time as well as offsets among taxa and pedogenic calcite (all measurements can be found in supplemental data archive Table 3):

1. Increases in $\delta^{18} \mathrm{O}_{\mathrm{p}}$ of ornithischian and small theropod terrestrial taxa from the lower to the upper Yellow Cat Member.

2. Increases in the $\delta^{18} \mathrm{O}_{\mathrm{p}}$ of semi-aquatic taxa and $\delta^{18} \mathrm{O}$ of pedogenic calcite from the upper Yellow Cat Member to the Ruby Ranch Member.

3. Decreases in $\delta^{18} \mathrm{O}_{\mathrm{p}}$ for herbivores from the upper Yellow Cat Member to the Ruby Ranch Member.

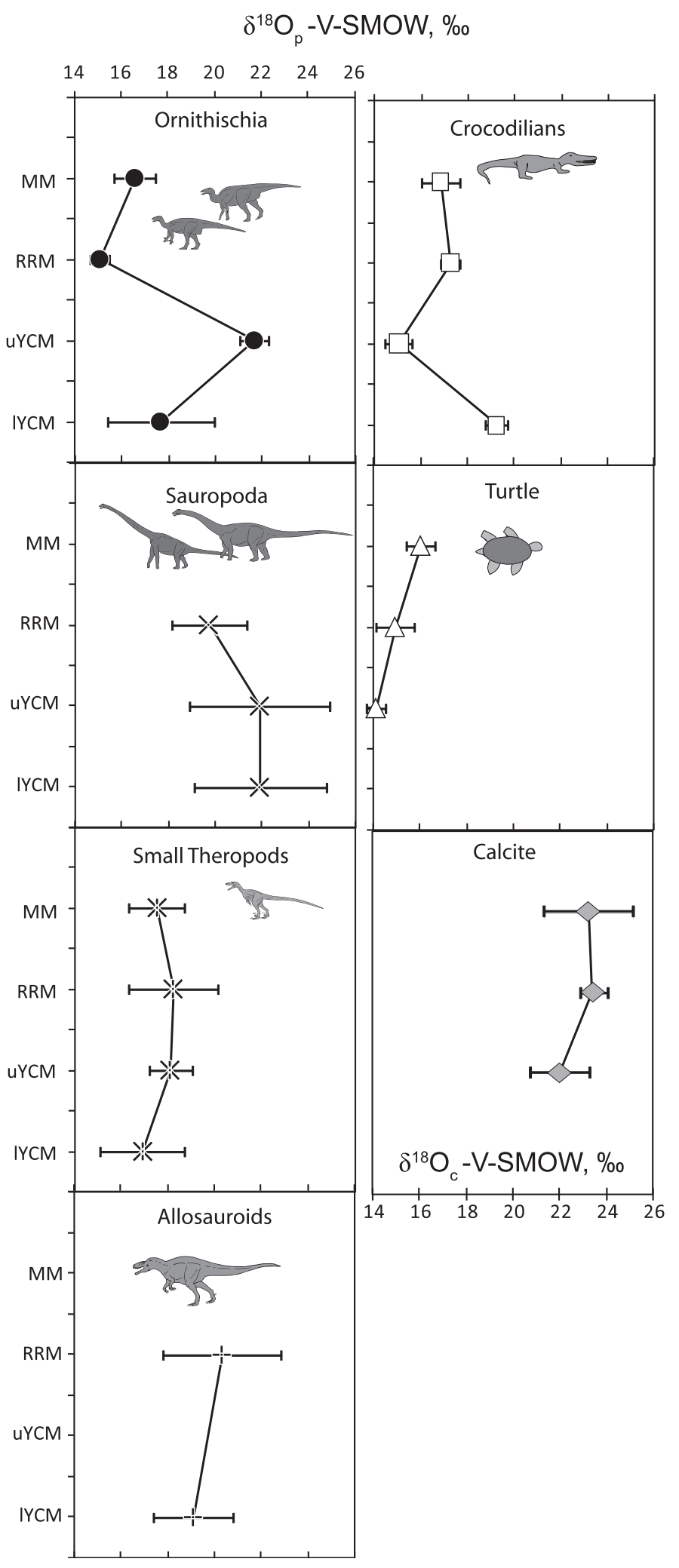

FIG. 3.-Average oxygen-isotope composition of phosphate and pedogenic calcite per taxa per site relative to V-SMOW. Sites are arranged in stratigraphic position from oldest (lower Yellow Cat Member) to youngest (Mussentuchit Member). Terrestrial taxa are in black symbols, semi-aquatic taxa are in white symbols, and calcite is in gray symbols. Error bars represent $1 \sigma$. 


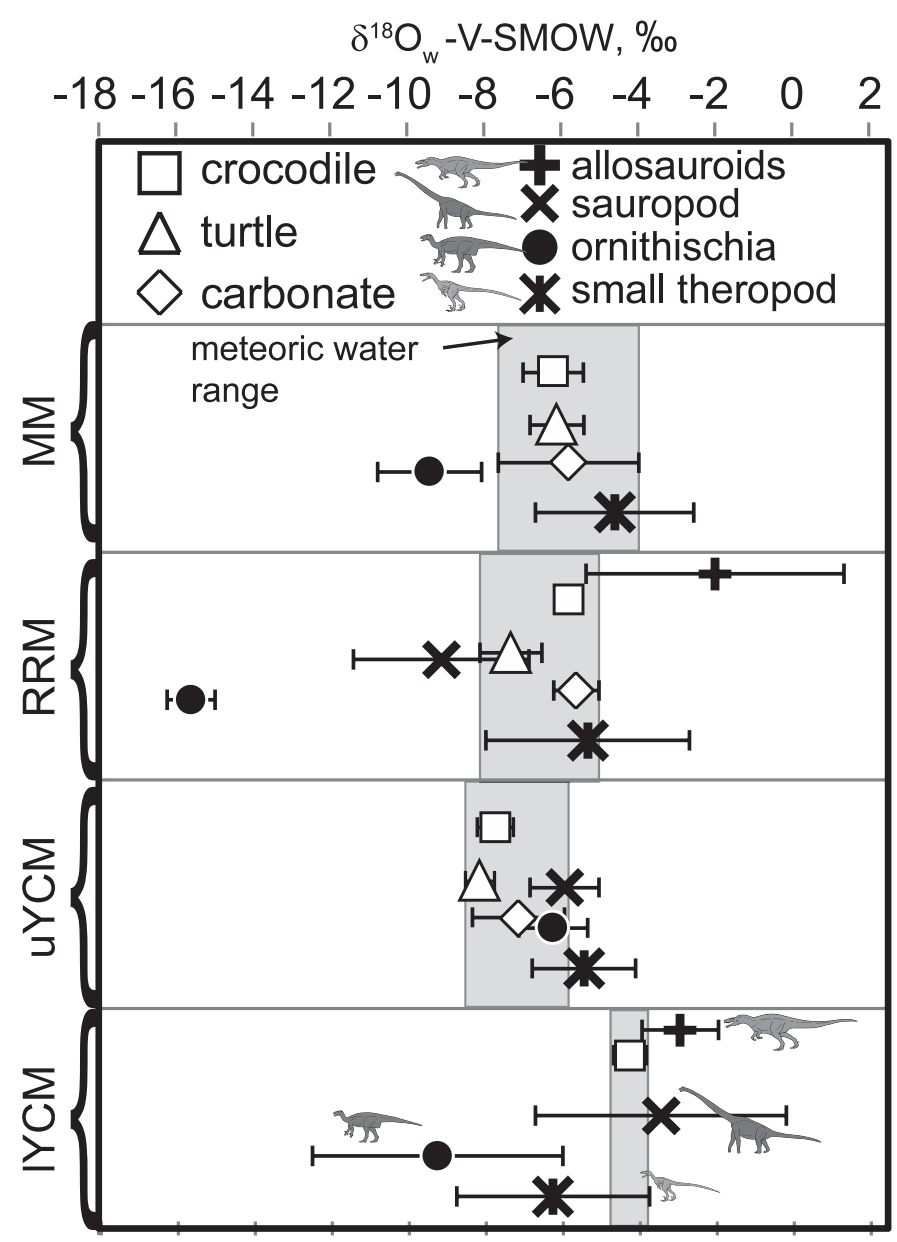

FIG. 4.-Calculated average ingested water for each semi-aquatic and terrestrial taxon relative to stratigraphic location. All semi-aquatic taxa are in white symbols and represent meteoric-water values (range shaded in gray). All terrestrial taxa are in black symbols. Error bars represent $1 \sigma$.

4. Higher $\delta^{18} \mathrm{O}_{\mathrm{p}}$ values for sauropods relative to other dinosaurs.

5. Lower $\delta^{18} \mathrm{O}_{\mathrm{p}}$ values for small theropods relative to other dinosaurs (except ornithischians from the Ruby Ranch Member).

For calculated water values:

1. The upper Yellow Cat Member has the lowest variability in calculated $\delta^{18} \mathrm{O}_{\mathrm{w}}$.

2. The Ruby Ranch Member has the greatest variability in calculated $\delta^{18} \mathrm{O}_{\mathrm{w}}$, the lowest $\delta^{18} \mathrm{O}_{\mathrm{w}}$ calculated ( -16.5 ornithischians), and highest $\delta^{18} \mathrm{O}_{\mathrm{w}}$ calculated ( -2.0 allosauroids).

3. Ornithischians have the lowest $\delta^{18} \mathrm{O}_{\mathrm{w}}$ calculated for all members

4. Allosauroids have the highest $\delta^{18} \mathrm{O}_{\mathrm{w}}$ calculated for all members.

5. Small theropod $\delta^{18} \mathrm{O}_{\mathrm{w}}$ mirrors meteoric-water proxies.

\section{Semi-Aquatic Taxa and Pedogenic Carbonate: Meteoric-Water Proxies}

Calcite, turtle, and crocodile compositions imply similar isotopic compositions of water (Table 2, Fig. 4). For the lower Yellow Cat Member, water estimated from crocodile teeth averaged $-4.2 \pm 0.4 \%$ o $(1 \sigma)$. For the upper Yellow Cat Member, estimated meteoric-water compositions are $-7.7 \pm 0.5 \%$ (crocodile scute), $-8.1 \pm 0.4 \%$ (turtles), and $-7.1 \pm 1.2 \%$ (pedogenic calcite). For the Ruby Ranch Member, estimated meteoric water compositions are $-5.8 \pm 0.3 \%$ (crocodile teeth), $-7.3 \pm 0.8 \%$ (turtle), and $-5.6 \pm 0.6 \%$ (pedogenic calcite). For the Mussentuchit Member estimated water compositions are $-6.2 \pm$ $0.8 \%$ (crocodile teeth), $-6.2 \pm 0.7 \%$ (turtle), and $-5.8 \pm 1.8 \%$ \% (pedogenic calcite).

For all sites, the $\delta^{18} \mathrm{O}_{\mathrm{w}}$ values interpreted from crocodile enamel vs. pedogenic calcite do not statistically differ, and for all sites except the Ruby Ranch Member, $\delta^{18} \mathrm{O}_{\mathrm{w}}$ values from turtles do not statistically differ from crocodiles and pedogenic calcite (t-tests with Bonferroni corrections; supplemental archive data Table 4). These data suggest that semi-aquatic taxa record local meteoric water. All these data compare well with the pedogenic calcite-based zonal average for $34^{\circ} \mathrm{N}$ paleolatitude $(-6.6$ to $-4.8 \%$; Suarez et al. 2011).

\section{Terrestrial Taxa}

Many reptiles employ various behavioral methods to regulate body temperatures and they grow only during optimal conditions (e.g., Kohn 1996; Barrick et al. 1999). A constant body temperature of $37^{\circ} \mathrm{C}$ has been suggested for dinosaurs (Amiot et al. 2006; Eagle et al. 2011). Thus, in principle drinking water $\delta^{18} \mathrm{O}$ can be estimated from dinosaur phosphate because: 1) the relationship between $\delta^{18} \mathrm{O}_{\mathrm{p}}$ and $\delta^{18} \mathrm{O}_{\mathrm{w}}$ is similar for most terrestrial taxa (Kohn 1996; Kohn and Cerling 2002) at least for non-arid environments, 2) dinosaurs are large-bodied terrestrial taxa, 3) there is increasing evidence that dinosaurs were able to maintain constant body temperatures (Barrick et al. 1996; Amiot et al. 2006) even at high latitudes with low mean annual temperatures where other reptiles, such as crocodiles and turtles, did not exist (e.g., Prince Creek Formation, Alaska; Fiorillo et al. 2010), and 4) environmental constraints (humidity and $\delta^{18} \mathrm{O}$ of consumed water) dominantly control the isotopic composition of terrestrial taxa. Dinosaur-based $\delta^{18} \mathrm{O}_{\mathrm{w}}$ allows comparison of water sources available to motile terrestrial vs. relatively sessile aquatic taxa.

Herbivorous Taxa.-Higher $\delta^{18} \mathrm{O}_{\mathrm{w}}$ values estimated from herbivorous terrestrial taxa from Eq. 4 overlap $\delta^{18} \mathrm{O}_{\mathrm{w}}$ calculated from turtles, crocodiles, and pedogenic calcite (Fig. 4, Table 2), but also extend to much lower $\delta^{18} \mathrm{O}_{\mathrm{w}}$ and vary widely within and between members. Application of Eq. 5 to herbivorous taxa for the relatively humid Mussentuchit and lower Yellow Cat members produces nearly identical results (within 1\%) between Eq. 5 and Eq. 3. Average values are statistically different for herbivorous taxa from member to member (Table A3a) and are depleted in ${ }^{18} \mathrm{O}$ relative to the meteoric water proxies for the Mussentuchit, Ruby Ranch, and lower Yellow Cat members. Average ingested water was lowest during deposition of the Ruby Ranch Member, as low as $-13.4 \%$ (sauropods) to $-16.5 \%$ (ornithischians), although values as low as $-13 \%$ were also reached in the Mussentuchit and upper Yellow Cat members.

Sauropods have the highest $\delta^{18} \mathrm{O}_{\mathrm{p}}$ of all herbivorous terrestrial taxa per member (e.g., 26.1\% in the upper Yellow Cat), suggesting either that they preferred a more enriched water source or had a greater proportional loss of ${ }^{16} \mathrm{O}$-rich water vapor. Sauropods also have the most variable $\delta^{18} \mathrm{O}_{\mathrm{p}}$, e.g., in the upper Yellow Cat Member the isotopic composition of consumed water ranged from 0.0 to $-13.1 \%$, whereas meteoric water ranged between -7.1 and $-8.7 \%$. Thus, sauropods must have sampled unusually variable water sources that presumably included ${ }^{18} \mathrm{O}$-depleted sources (e.g., high-elevation-sourced river water), local meteoric water, and ${ }^{18} \mathrm{O}$-enriched plant leaves. Migration between isotopically enriched and depleted water sources (e.g., coastal plain versus highlands) is possible but cannot be evaluated without additional data such as $\mathrm{Sr}$ isotopes. Alternatively, physiological changes during ontogeny might induce extreme intra-species variation. For example, if physiology and dependence on water sources or proportional changes in food intake changed during the growth of the animal, significant changes in body 
water isotopic composition could result. Recent research on sauropod physiology suggests they may have significantly changed growth rates and metabolic states during the course of ontogeny to reach such large sizes (Sander et al. 2011). Tooth length and isotopic composition do correlate strongly, but without complete jaws of varying size, tooth size might correspond to different eruptive states rather than age.

Ornithischians (iguanodontids, ornithopods, and polocanthine ankylosaurs) generally exhibit the lowest $\delta^{18} \mathrm{O}_{\mathrm{w}}$ values of the herbivores, below that of crocodiles, sauropods, and turtles (except in the upper Yellow Cat Member; Table 2, Fig. 4). Average $\delta^{18} \mathrm{O}_{\mathrm{w}}$ ranges between -6.2 and $-15.5 \%$, with a minimum value of $-16.5 \%$ in the Ruby Ranch Member. Consistently lower ornithischian $\delta^{18} \mathrm{O}_{\mathrm{w}}$ compared to sauropods may indicate that ornithischians were obligate drinkers. If they drank water year round, they likely preserve the yearly isotopic composition of river water. This value could be lower than local meteoric water if sourced from higher-elevation precipitation.

Carnivorous Taxa.-Allosauroid $\delta^{18} \mathrm{O}_{\mathrm{w}}$ is $2-4 \%$ higher than that of small theropods and up to $5 \%$ higher than that of pedogenic calcite, turtles, and crocodiles (Table 2, Fig. 4). Application of Eq. 5, however, suggests $\delta^{18} \mathrm{O}_{\mathrm{w}}$ similar to that of meteoric water. Thus, their ingested water was certainly ${ }^{18} \mathrm{O}$-enriched relative to water ingested by small theropods and possibly also relative to local meteoric water. Allosauroids also show highly variable compositions. Many carnivores ingest most of their water from food (Kohn 1996). Possibly allosauroids preferentially preyed on sauropods, which would confer higher and more variable $\delta^{18} \mathrm{O}$ relative to small theropods. Estimated $\delta^{18} \mathrm{O}_{\mathrm{w}}$ from small theropods (likely dromaeosaurids) is comparable to that of local meteoric water.

\section{DISCUSSION}

\section{Implications for the Rise of the Nevadaplano and Regional Climate}

The $\delta^{18} \mathrm{O}_{\mathrm{w}}$ values of terrestrial taxa (sauropods, ornithischians, and small theropods), semi-aquatic taxa (turtles and crocodiles), and calcite and indicators from sedimentology and paleosols allow us to interpret climatic effects of the rise of the Sevier Mountains and resulting Nevadaplano. Since allosauroid data were collected only from the lower Yellow Cat and Ruby Ranch Members we do not use them in this interpretation.

The data from the lower Yellow Cat member shows a wide degree of scatter in the data. Meteoric water interpreted from crocodile isotopes suggests a value that is on the heavy end for this paleolatitude $(-4.3 \%)$. However, isotopic enrichment of crocodile body water may account for this since some mesosuchians from the Early Cretaceous are more terrestrial in nature than modern eusuchians tested in the Amiot et al. (2007) model. Dinosaur-ingested water is similar to meteoric water (calculated from crocodiles) for sauropods and lighter from ornithischians and small theropods, suggesting some isotopically light water source, as low as $-14.8 \%$ (minimum value for ornithischians). Such low values generally imply snowfall or orographically depleted precipitation. That is, Sevier Mountains must have been sufficiently high as early as during deposition of the lower Yellow Cat Member to potentially produce snow with (at least seasonal) runoff into our study area (Fig. 5A). Alternative sources that can produce isotopically light water values such as springs cannot be discounted. However, with the exception of geothermal spring waters, most springs are sourced from higher elevations (i.e., the same source of water runoff). There are spring deposits documented in the upper Yellow Cat member (C. Suarez et al. 2007; M. Suarez et al. 2007), but no isotopic measurements of these springs have been made. Carbonate oncoids from the Buckhorn Conglomerate (correlative to the Poison Strip or the basal Ruby Ranch in this location) were measured by Shapiro et al. (2009) and suggest water values that average $-7.25 \%$, similar to the meteoric water values averaged from the entire formation from other carbonates, lighter that of crocodile ingested water $(4.3 \%)$, and closer to that of small theropods. A study of the modern Crystal Geyser cold spring gives values $(\sim-14 \%)$ similar to that of surface water in the Green River $(\sim-15 \%)$, which is sourced from the Navajo aquifer and highlands in the vicinity of the Uinta Mountains (Wilkinson et al. 2009).

From the lower to the upper Yellow Cat Member, the data suggest initiation of rain-shadow effects of the Sevier Mountains (Fig. 5B). Sedimentological changes towards increased precipitation of pedogenic calcite and increased intermittent to ephemeral alluvial systems (Elliott et al. 2007) suggest increases in aridity. The range in water isotope values decreases to its minimum variance during upper Yellow Cat time (see low standard deviation error bars and confluence of average isotope values in Fig. 4). This suggests few extremes in water isotopic composition. All values of dinosaur ingested water (min, max, and averages) increase slightly, with the exception of sauropods suggesting increased aridity. This suggests that influences of orographically depleted water values are counteracted by increases of aridity in the study area and isotopic enrichment of $\delta^{18} \mathrm{O}_{\mathrm{p}}$ values. Both sedimentology and isotope data are logically linked to increasing Sevier elevations to the west, enhancing a rain shadow over the study area. Low $\delta^{18} \mathrm{O}_{\mathrm{w}}$ for sauropod dinosaurs, however, imply at least seasonally low $\delta^{18} \mathrm{O}$ water sources (approaching $-13.1 \%$ ) already during deposition of the Yellow Cat Member, for example from rivers not sampled by turtles or crocodiles. Such low values generally imply snowfall, likely sourced from western snowmelt.

Between the upper Yellow Cat and Ruby Ranch members lithology and data suggest that the height of the Sevier Mountains is reaching its maximum for the CMF depositional time period and rain-shadow effects are at its maximum (Fig. 5C). Increased aridity is seen in sedimentologic data in which we observe increased amounts of pedogenic carbonates that include dolomite, dolomitic and high- $\mathrm{Mg}$ calcite lake deposits, and abundant red beds suggesting xeric environments. For isotopic data, mean, maximum, and minimum $\delta^{18} \mathrm{O}_{\mathrm{w}}$ values increase slightly for meteoric-water proxies but decrease drastically for dinosaurs. This significant decrease in $\delta^{18} \mathrm{O}_{\text {dinosaur water suggests a high probability of }}$ seasonal snow precipitation. The Ruby Ranch isotope data also see the greatest variability in average, minimum, and maximum values suggesting drastic seasonal changes. Although data scatter considerably, these trends may indicate further increases in elevation, evaporatively enriching local water sources in ${ }^{18} \mathrm{O}$ but further decreasing river $\delta^{18} \mathrm{O}$.

From the Ruby Ranch to Mussentuchit members, inconsistent shifts to meteoric-water proxy and dinosaur isotopes suggest static elevations. However, decreased elevations or a seasonal shift to an alternate water source would explain an increase in relative humidity (Suarez et al. 2011, 2012), a decrease in abundance of pedogenic carbonate, and presence of water-dependent taxa such as frogs and salamanders (Cifelli et al. 1999). General-circulation models suggest a shift in prevailing summer wind directions from westerlies during the Albian (c. $105 \mathrm{Ma}$ ) to easterlies during the Turonian (c. $90 \mathrm{Ma}$; Poulsen et al. 1999) due to the presence of the Western Interior Seaway (Fig. 5D). Consequently, we favor a shift to summer precipitation patterns to explain sedimentologic characteristics, inconsistent isotopic shifts, and faunal differences between the Mussentuchit and Ruby Ranch members.

For most of the section we studied, prevailing westerlies off the Pacific Ocean should have delivered significant precipitation. Thus changes to the height of the intervening Sevier Mountains should have controlled both overall aridity and isotope compositions of local water. Our data suggest an increase in the height of the Sevier Mountains from at least the lower Yellow Cat to upper Yellow Cat members (between c. 135 and $120 \mathrm{Ma}$ ), and the Ruby Ranch Member (c. $110 \mathrm{Ma}$ ), with greatest climatic effects in the Ruby Ranch Member. Elevations could have decreased slightly or remained static during deposition of the Mussentuchit Member (c. 95-100 Ma), and climatic effects of the encroaching 

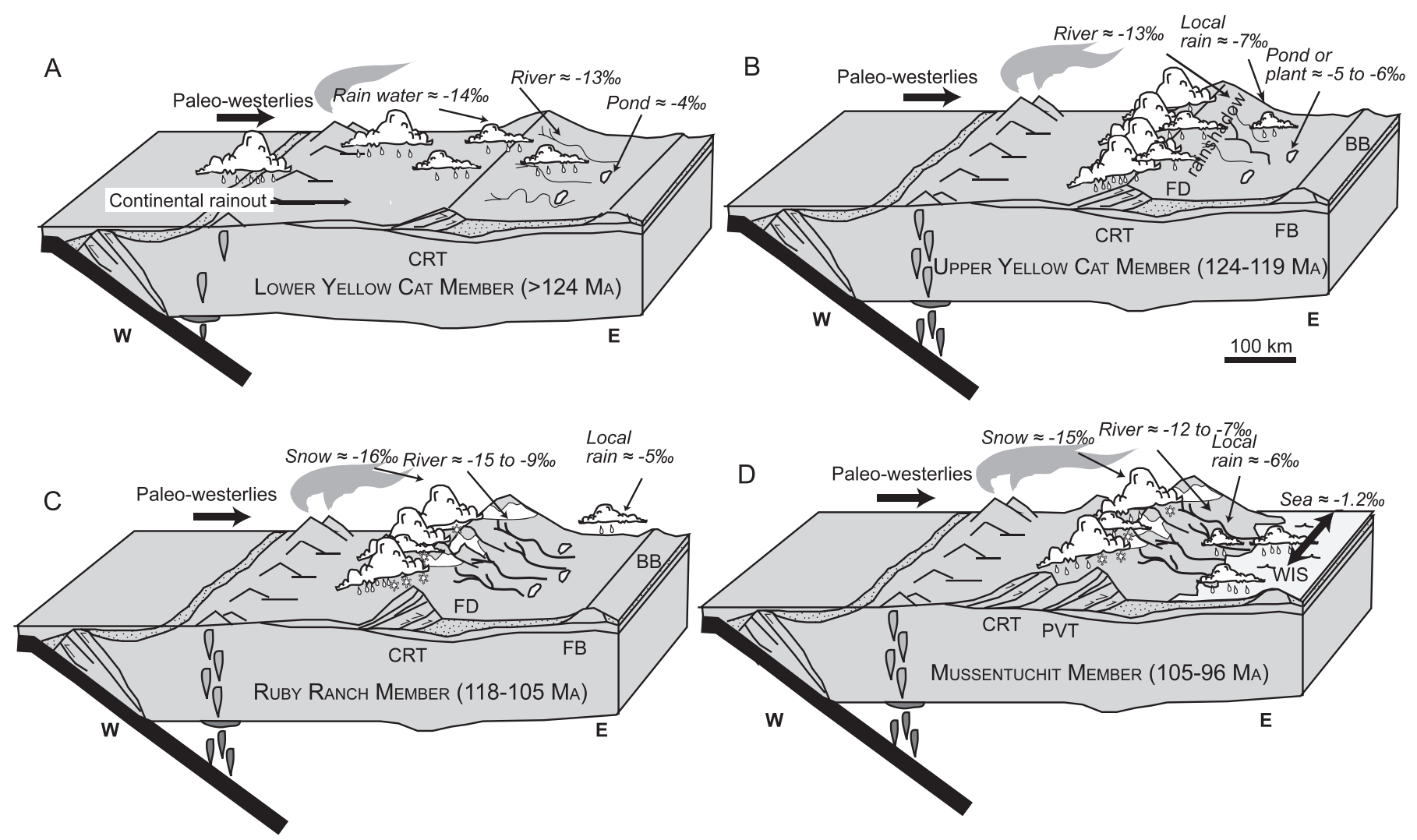

FIG. 5.-Block diagrams of interpreted paleoclimatic and paleogeographic settings represented by the isotopic composition of each fauna. A) Lower Yellow Cat Member: Canyon Range Thrust initiated uplifted highlands (Sevier Mountains) to the west. Climate was semihumid-semiarid. Rivers were isotopically depleted as recorded by the ornithischian ingested water due to continental rainout or potential seasonal snowmelt. B) upper Yellow Cat Member time: Sevier Mountains increased in height, resulting in significant rainout on the western and crest of the mountains. The rainshadow created arid conditions on the leeward side of the mountains. C) Ruby Ranch Member time: paleo-elevations reach their maximum for the Canyon Range thrust causing a rain shadow and slight enrichment of meteoric water. Elevations were high enough for seasonal snowfall in the mountains that provided depleted river water discharged to the foreland basin. D) Initiation of the Pavant Thrust event began, increasing elevation; however, incursion of the Western Interior Seaway (WIS) provided significantly enriched moisture (lack of rainout) to the region. FD, foredeep; FB, forebulge; BB, backbulge (modified from Elliott et al. 2007).

Western Interior Seaway resulted in a more humid climate. Much later in the history of the Sevier Mountains (c. 60-75 Ma), clumped-isotope paleothermometry and $\delta^{18} \mathrm{O}$ values for pedogenic carbonate and lacustrine carbonate imply a height of the Sevier Mountains and the Nevadaplano between 2.2 and $3.1 \mathrm{~km}$ and definitely $>2 \mathrm{~km}$ (Snell et al. 2014). Local water compositions were as low as $-10 \%$, so lower than our estimates of $\delta^{18} \mathrm{O}_{\mathrm{w}}$ from pedogenic calcite, crocodiles, and turtles, but higher than many values estimated from dinosaurs. Together these data suggest an increase in mean elevation through time, but with substantially higher local elevations. Coarse-grained sediments in the Cedar Mountain and later formations are consistent with sustained substantial relief.

\section{Greenhouse Climates and Comparisons of Meteoric-Water Proxies with Zonal Averages}

It is clear that local orogenic events significantly affected regional hydrology and climate changes (aridity) during deposition of the CMF, particularly in the composition of river water. On the formation level as a whole, however, our data fit an image of an intensified global hydrologic cycle caused by the mid-Cretaceous global warmth. Latitudinal effects (documented by the global pedogenic carbonate record) during the Aptian-early Cenomanian resulted in depletion of ${ }^{18} \mathrm{O}$ of meteoric water as a consequence of increased rainout and isotopic fractionation at progressively higher latitudes (Ufnar et al. 2002, 2004; Suarez et al. 2009). When compared to the zonal average of $\delta^{18} \mathrm{O}_{\mathrm{w}}$ for $34^{\circ} \mathrm{N}$ paleolatitude estimated by pedogenic calcite, turtle-generated and crocodile-generated $\delta^{18} \mathrm{O}_{\mathrm{w}}$ are remarkably similar (Fig. 6). The carbonate data documented here include samples from the early Aptian (upper Yellow Cat Member), so extend the lower portion of the range in meteoric water documented from carbonates to a minimum of $-7.1 \pm 1.2 \%$. The mutual consistency of multiple local meteoric-water proxies support previously determined zonal meteoric-water values and $\delta^{18} \mathrm{O}$ groundwater gradients (Ufnar et al. 2002, 2004; Suarez et al. 2009), as well as the use of pedogenic-carbonate records for global-scale paleohydrologic reconstructions. These data also support use of turtles and crocodiles as meteoric-water proxies in globalscale paleohydrologic reconstructions. By combining all three proxies, researchers can generate more robust reconstructions of ancient paleohydrology and climates.

\section{Implications}

These data show successful utilization of isotopic proxies for continental paleoecologic and paleoclimatic studies of ecosystems as old as the Mesozoic. Combinations of isotope data from pedogenic calcite and terrestrial versus semi-aquatic taxa and consideration of likely habits and physiological effects yield new insights into climatic impacts of orogeny and marine transgressions. We also, for the first time, isotopically corroborate the presence of a rain shadow, suggested by Elliott et al. (2007), for the "Nevadaplano" of DeCelles and Coogan (2006). The rise of the Sevier Mountains significantly affected climate by 

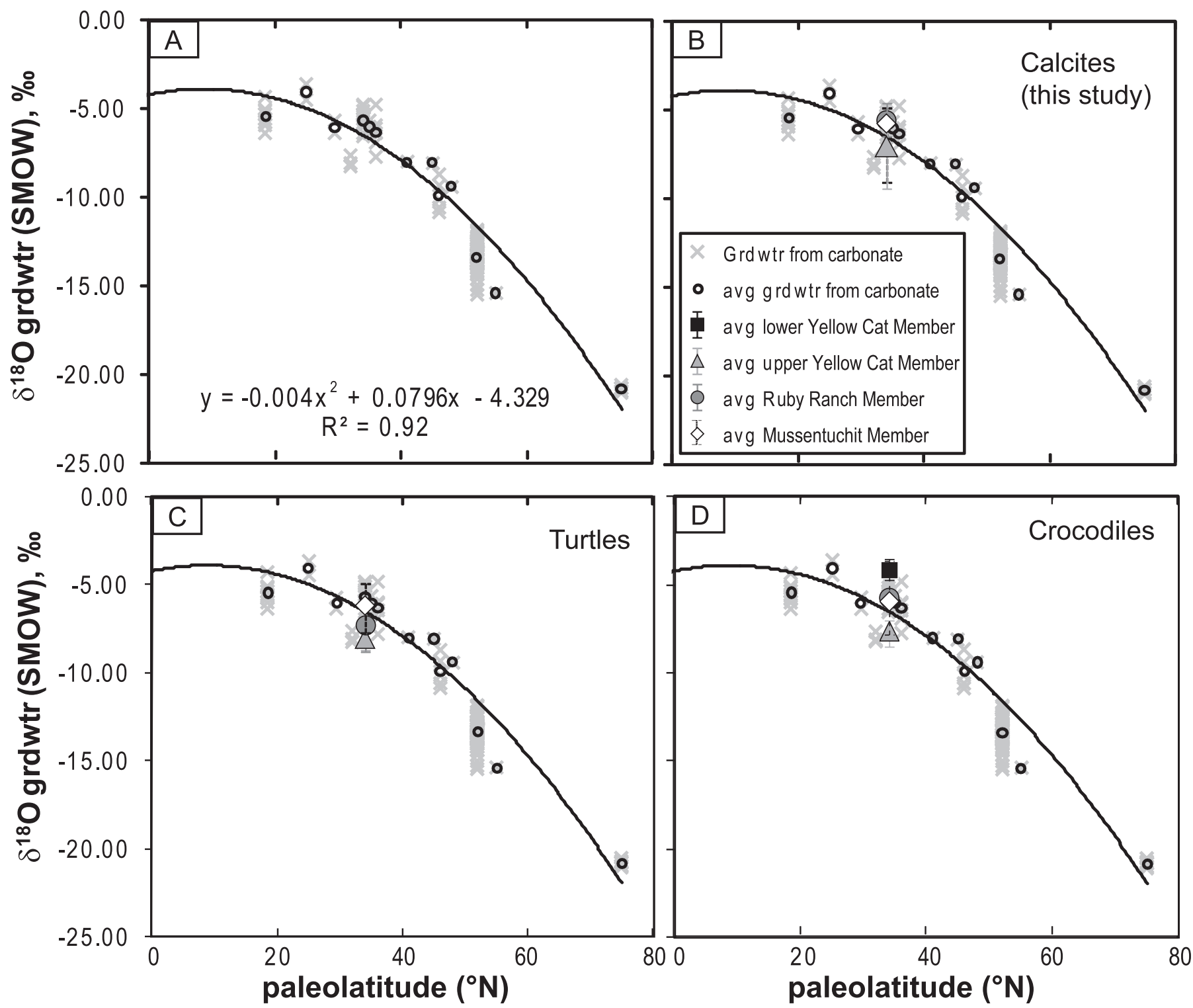

FIG. 6.-Global-scale comparison of the North American groundwater $\delta^{18} \mathrm{O}$ gradient derived from A) pedogenic carbonate of Suarez et al. 2011 relative to B) pedogenic calcites from this study, C) turtles, and D) crocodiles at $34^{\circ} \mathrm{N}$ paleolatitude. Error bars represent the maximum and minimum calculated water values. Turtles and crocodiles fall on the calculated second-order polynomial trend.

$\sim 124 \mathrm{Ma}$ (upper Yellow Cat Member fauna) and was sustained through at least 95-100 Ma (Mussentuchit Member faunas; Fig. 5). Incursions of WIS-dominated weather patterns from the southeast by 98-96 Ma may have produced wetter conditions, although local orographic effects during the Pavant thrust are still evident (Fig. 5). Carbonate, turtle, and crocodile data are proxies for meteoric water, but without coexisting terrestrial (dinosaurian) taxa, we would not have been able to accurately identify the rain shadow effects of the SFTB on regional climate or highelevation drainage composition. The success of this study suggests that a similar data set can be used to identify orographic effects versus effects of global climate change.

\section{CONCLUSIONS}

One of the most extensive (590 individual measurements) isotopic data sets for the early to mid-Cretaceous, including semi-aquatic taxa (turtles and crocodiles) terrestrial taxa (carnivorous and herbivorous dinosaurs) and pedogenic carbonate, imply:

1. Late Aptian-early Cenomanian zonal averages of $\delta^{18} \mathrm{O}_{\mathrm{w}}$ for $34^{\circ} \mathrm{N}$ paleolatitude are consistent with the latitudinal $\delta^{18} \mathrm{O}$ groundwater gradient documented by Ufnar et al. (2002, 2004), White et al. (2001), and Suarez et al. (2009) and range between -4.2 to $-8.1 \%$ and average $-6.4 \%$.

2. Calculated values of $\delta^{18} \mathrm{O}_{\mathrm{w}}$ and inter-taxon comparisons suggest that sauropods and larger theropods such as allosauroids consumed isotopically enriched water relative to small theropods and ornithischians, which likely relied on river water.

3. Dinosaurs from the Cedar Mountain Formation record river water compositions that were depleted relative to meteoric water by as much as $5-10 \%$, suggesting that they drank river water sourced from the Sevier Mountain highlands. 
4. The isotopic composition from a variety of taxa suggests that formation of the "Nevadaplano" (DeCelles and Coogan 2006) helped force local climate during deposition of the CMF. A rainshadow progressively intensified from lower Yellow Cat to Ruby Ranch times (c. 135 to $110 \mathrm{Ma}$ ), and snow was likely present at least locally at proximal high elevations throughout CMF deposition.

5. Changes to the geography of the Western Interior Seaway and consequent changes to atmospheric and ocean circulation patterns introduced seasonal (likely summer) moisture and resulted in warm humid conditions during the late Albian-Cenomanian (Mussentuchit, 110-86 Ma).

The combined analysis of continental taxa of various physiologies and ecology with analysis of pedogenic carbonates can potentially elucidate regional climate change due to forcings such as orogenic effects and marine regression and transgression. It is unclear if global climate changes such as the "Selli" event associated with OAEla contributed to climate during the formation of the CMF. Future work to identify the carbon isotope excursions within the CMF may help to elucidate the combined effects of regional orogeny and global climate change.

\section{ACKNOWLEDGEMENTS}

We would like to thank the many officials and institutions for access to material for isotopic analysis including Dr. Brooks Britt and Rod Sheetz from Brigham Young University Museum of Paleontology, John Bird, Dr. Reese Barrick (Sternberg Museum of Natural History), and Jeff Bartlett from College of Eastern Utah, Dr. Ken Carpenter from the Denver Museum of Nature and Science, Jennifer Larsen from the Sam Noble Oklahoma Museum of Natural History, Don DeBlieux and Scott Madsen from the Utah Geological Survey, and Dr. Randy Irmis and Mike Getty from the Utah Museum of Natural History. We also thank Dr. Scott Foss of the Bureau of Land Management for final approval of destructive sampling. Funding for this project was provided to C. Suarez by grants from the Paleontological Society Stephen J. Gould Student Research Award, Sigma Xi Grant-in-Aid of Research Program, and by National Science Foundation grant EAR-0325072 to González and Ludvigson at the University of Kansas.

\section{SUPPLEMENTAL MATERIAL}

Four tables are available from JSR's Data Archive: http://sepm.org/pages. aspx? pageid $=229$.

\section{REFERENCES}

AL-SuwaIDI, A.H., 2007, A ped's story [MS thesis]: Lawrence, University of Kansas, $135 \mathrm{p}$.

Amiot, R., Lécuyer, C., Buffetaut, E., Escarguel, G., Fluteau, F., and Martineau, F., 2006, Oxygen isotopes from biogenic apatites suggest widespread endothermy in Cretaceous dinosaurs: Earth and Planetary Science Letters, v. 246, p. 41-54.

Amiot, R., Lécuyer, C., Escarguel, G., Billon-Bruyat, J.P., Buffetaut, E., Langlois, C., Martin, S., Martineau, F., and Mazin, J.M., 2007, Oxygen isotope fractionation between crocodilian phosphate and water: Palaeogeography, Palaeoclimatology, Palaeoecology, v. 243, p. 412-420.

AuBREY, W.M., 1998, A newly discovered, widespread fluvial facies and unconformity marking the Upper Jurassic/Lower Cretaceous boundary, Colorado Plateau, in Carpenter, K., Chure, D., and Kirkland, J.I., eds., The Upper Jurassic Morrison Formation: An Interdisciplinary Study, Part I: Modern Geology, v. 22, p. 209-233.

BarRick, R.E., SHOWERs, W.J., AND Fisher, A.L., 1996, Comparison of thermoregulation of four Ornithischian dinosaurs and a varanid lizard from the Cretaceous Two Medicine Formation: evidence from oxygen isotopes: Palaios, v. 11, p. 295-305.

Barrick, R.E., Fisher, A.L., AND Showers, W.J., 1999, Oxygen isotopes from turtle bone: applications for terrestrial paleoclimates: Palaios, v. 14, p. 186-191.

Bassett, D., MacLeod, K.G., Miller, J.F., and Ethington, R.L., 2007, Oxygen isotopic composition of biogenic phosphate and the temperature of Early Ordovician Seawater: Palaios, v. 22, p. 98-103.

Bellanca, A., Erba, E., Neri, R., Silva, I.P., Sprovieri, M., Tremolada, F., and Verga, D., 2002, Palaeoceanographic significance of the Tethyan "Livellow Selli" (Early Aptian) from the Hybla Formation, northwest Sicily: biostratigraphy and highresolution chemostratigraphic records: Palaeogeography, Palaeoclimatology, Palaeoecology, v. 185, p. 175-196.
Billon-Bruyat, J.P., Lécuyer, C., Martineau, F., and Mazin, J.M., 2005, Oxygen isotope compositions of Late Jurassic vertebrate remains from lithographic limestones of western Europe: implications for the ecology of fish, turtles, and crocodilians: Palaeogeography, Palaeoclimatology, Palaeoecology, v. 216, p. 359-375.

Breecker, D.O., Sharp, Z.D., and McFadden, L.D., 2009, Seasonal bias in the formation and stable isotopic composition of pedogenic carbonate in modern soils from central New Mexico, USA: Geological Society of America, Bulletin, v. 121, p. $630-640$.

Britt, B.B., Burton, D., Greenhalgh, B.W., Christiansen, E., and Chure, D., 2007, Detrital zircon ages for the basal Cedar Mountain Formation (Early Cretaceous) near Moab, and Dinosaur National Monument, Utah [Abstract]: Geologogical Society of America, Abstracts with Programs, v. 39, p. 16.

Britt, B.B., Eberth, D.A., Scheetz, R., Greenhalgh, B.W., and Stadtman, K.L. 2009, Taphonomy of debris-flow dinosaur bonebeds at Dalton Wells, Utah (Lower Cretaceous, Cedar Mountain Formation, USA: Palaeogeography, Palaeoclimatology, Palaeoecology, v. 280, p. 1-22.

Cerling, T.E., and Quade, J., 1993, Stable carbon and oxygen isotopes in soil carbonates, in Swart, P., Lohmann, K.C., McKenzie, J., and Savin, S., eds., Continental indicators of climate: American Geophysical Union, Geophysical Monograph 78, p. 217-231.

Chenery, C., Müldner, G., Evans, J., Eckardt, H., and Lewis, M., 2010, Strontium and stable isotope evidence for diet and mobility of Roman Gloucester, U.K.: Journal of Archaeological Science, v. 37, 150-163.

Cifelli, R.L., Nydam, R.L., Gardner, J.D., Weil, A., Eaton, J.G., Kirkland, J.I., and Madsen, S.K., 1999, Medial Cretaceous Vertebrates from the Cedar Mountain Formation, Emery County, Utah: The Mussentuchit Local Fauna, in Gillette, D.D., ed., Vertebrate Paleontology in Utah: Utah Geological Survey, Miscellaneous Publications 99-1, p. 219-242

Clementz, M.T., and Koch P.L., 2001, Differentiating aquatic mammal habitat and foraging ecology with stable isotopes in tooth enamel: Oecologia, v. 129, p. 461-472.

Coulson, A.B., Kohn, M.J., Shirley, M.H., Joyce, W.G., and Barrick, R.E., 2008 , Phosphate-oxygen isotopes from marine turtle bones: ecologic and paleoclimatic applications: Palaeogeography, Palaeoclimatology, Palaeoecology, v. 264, p. 78-84.

CurRIE, B.S., 1998, Upper Jurassic-Lower cretaceous Morrison and Cedar Mountain Formations, NE Utah-NW Colorado: relationships between non-marine deposition and early cordilleran forland-basin development: Journal of Sedimentary Research, v. 68 , p. $632-652$

Currie, B.S., 2002, Structural configuration of the Early Cretaceous cordilleran foreland-basin system Sevier Thrust Belt, Utah and Colorado: Journal of Geology, v. 110 , p. $697-718$.

Decelles, P.G., And Coogan, J.C., 2006, Regional structure and kinematic history of the Sevier fold-and-thrust belt, central Utah: Geological Society of America, Bulletin, v. 118 , p. $841-864$.

Dettman, D.L., And Lohmann, K.C., 2000, Oxygen isotope evidence from high altitude snow in the Laramide Rocky Mountains of North America during the later Cretaceous and Paleogene: Geology, v. 28, p. 243-246.

Doelling, H.H., and Kuehne, P.A., 2013, Geologic map of the Short Canyon Quadrangle, Emery County, Utah: Utah Geologicial Survey, Map 255DM.

Dumitrescu, M., Brassell, S.C., Schouten, S., Hopmans, E.C., and SinningheDamste, J.S., 2006, Instability in tropical Pacific sea-surface temperatures during the early Aptian: Geology, v. 34, p. 833-836.

Dutton, A., Wilkinson, B.H., Welker, J.M., Bowen, G.J., And Lohmann, K.C., 2005 , Spatial distribution and seasonal variation in ${ }^{18} \mathrm{O} /{ }^{16} \mathrm{O}$ of modern precipitation and river water across the conterminous USA: Hydrological Processes, v. 19, p. 41214146.

Eagle, R.A.,Tütken, T., Martin, T.S., Tripati, A.K., Fricke, H.C., Connely, M., Cifelli, R.L., AND Eiler, J.M., 2011, Dinosaur body temperatures determined from isotopic $\left({ }^{13} \mathrm{C}-{ }^{18} \mathrm{O}\right)$ ordering in fossil biominerals: Science, v. 333, no. 6041, p. 443-445.

Eberth, D.A., Britt, B.B., Scheetz, R., Stadtman, K.L., and Brinkman, D.B., 2006, Dalton Wells: geology and signiciance of a debris-flow-hosted dinosaur bonebed in the Cedar Mountain Formation (Lower Cretaceous) of eastern Utah, USA Palaeogeography, Palaeoclimatology, Palaeoecology, v. 236, p. 217-245.

Elliott, W.S., SutTNER, L.J., AND PRATt, L.M., 2007, Tectonically induced climate and its control on the distribution of depositional systems in a continental foreland basin, Cloverly and Lakota formations (Lower Cretaceous) of Wyoming, USA: Sedimentary Geology, v. 202, p. 730-753.

ERICKSON, G.M., 1996, Incremental lines of von Ebner in dinosaurs and the assessment of tooth replacement rates using growth line counts: National Academy of Sciences, USA, Proceedings, v. 93, no. 25, p. 14,623-14,627.

Farquhar, G.D., Ehleringer, J.R., and Hubick, K.T., 1989, Carbon isotope discrimination and photosynthesis: Annual Review of Plant Physilogy and Plant Molecular Biology, v. 40, p. 503-537.

Fiorillo, A.R., McCarthy, P.J., Flaig, P.P., Brandlen, E., Norton, D.W., Zippi, P., JACOBS, L.L., AND GANGloff, R.A., 2010, Paleontology and paleoenvironmental interpretation of the Kikak-Tegoseak Quarry (Prince Creek Formation: Late Cretaceous), northern Alaska: a multi-disciplinary study of a high-latitude ceratopsian dinsaur bonebed, in Ryan, M.J., Chinnery-Allgeier, B.J., and Eberth, D.A., eds., New Perspectives on Horned Dinosaurs: Bloomington, Indiana, Indiana University Press, p. 456-477.

Flanagan, L.B., and Ehleringer, J.R., 1991, Stable isotope composition of stem and leaf water: applications to the study of plant water use: Functional Ecology, v. 5, p. $270-277$. 
Fricke, H.C., Rogers, R.R., Backlund, R., Dwyer, C.N., and Echt, S., 2008, Preservation of primary stable isotope signals in dinosaur remains, and environmental gradients of the Late Cretaceous of Montana and Alberta: Palaeogeography, Palaeoclimatology, Palaeoecology, v. 266, p. 13-27.

Fricke, H.C., Rogers, R.R., AND Gates, T.A., 2009, Hadrosaurid migration: inferences based on stable isotope comparisons among Late Cretaceous dinosaur localities: Paleobiology, v. 35, p. 270-288.

Garrison, J.R., Jr., Brinkman, D.B., Nichols, D.J., Layer, P., Burge, D., and Thayn, D., 2007, A multidisciplinary study of the Lower Cretaceous Cedar Mountain Formation, Mussentuchit Wash, Utah: a determination of the paleoenvironment and paleoecology of the Eolambia caroljonesa dinosaur quarry: Cretaceous Research, v. 28, p. $461-494$.

GreenHalgh, B.W., 2007, A stratigraphic and geochronologic analysis of the Morrison Formation/Cedar Mountain Formation boundary, Utah [MS thesis]: Provo, Brigham Young University, $61 \mathrm{p}$

Grocke, D.R., Hesselbo, S.P., And Jenkyns, H.C., 1999, Carbon-isotope composition of Lower Cretaceous fossil wood: ocean-atmosphere chemistry and relation to sealevel change: Geology, v. 27, p. 155-158.

Herrle, J.O., Köbler, P., Friedrich, O., Erlenkeuser, H., and Hemleben, C., 2004, High-resolution carbon isotope records of the Aptian to Lower Albian from SE France and the Mazagan Plateau (DSDP Site 545): a stratigraphic tool for paleoceanographic and paleobiologic reconstruction: Earth and Planetary Science Letters, v. 218, p. 149-161.

JENKYNS, H.C., 2003, Evidence for rapid climate change in the Mesozoic-Paleogene greenhouse world. Royal Society of London, Philosophical Transactions A, v. 361, p. 1885-1916.

Kirkland, J.I., 1998, A new hadrosaurid from the Upper Cretaceous Cedar Mountain Formation (Albian-Cenomanian Cretaceous) of eastern Utah: the oldest known hadrosaurid (Lambeosaurine?), in Lucas, S.G., Kirkland, J.I., and Estep, J.W., eds., Lower and Middle Cretaceous Ecosystems: New Mexico Museum of Natural History and Sciences, Bulletin 14, p. 283-295.

Kirkland, J.I., and Madsen, S.K., 2007, The Lower Cretaceous Cedar Mountain Formation, Eastern Utah: the view up an always interesting learning curve (Geological Society of America, Rocky Mountain Section, Field Trip): Utah Geological Association, Field Tripe Guide, v. 35, 108 p.

Koch, P.L., 1998, Isotopic reconstruction of past continental environments: Annual review of Earth and Planetary Sciences, v. 26, p. 573-613.

Koch, P.L., Behrensmeyer, A.K., Tuross, N., And Fogel, M.L., 1989, Isotopic fidelity during bone weathering and burial: Carnegie Institution, Geophysical Laboratory, Annual Report of the Director, p. 105-110.

KoHn, M.J., 1996, Predicting animal $\delta^{18} \mathrm{O}$ : accounting for diet and physiological adaptation: Geochimica et Cosmochimica Acta, v. 60, p. 4811-4829.

Kohn, M.J., and Cerling, T.E., 2002, Chapter 12: Stable isotope composition of biological apatite in Kohn, M.J., Rakovan, J., and Hughes, J.M., eds., Reviews in Mineralogy and Geochemistry, v. 48, p. 455-488.

Kohn, M.J., and Dettman, D.L., 2007, Paleoaltimetry from stable isotope compositions of fossils: Reviews in Mineralogy and Geochemistry, v. 66, p. 119-154

Kohn, M.J., And Law, M.J., 2006, Stable isotope chemistry of fossil bone as a new paleoclimate indicator: Geochimica et Cosmochimica Acta, v. 70, p. 931-946.

Kolodny, Y., Luz, B., Sander, M., and Clemens, W.A., 1996, Dinosaur bones: fossils or pseudomorphs? The pitfalls of physiology reconstruction from apatitic fossils: Palaeogeography, Palaeoclimatology, Palaeoecology, v. 126, p. 161-171.

Kowallis, B.J., Britt, B.B., Greenhalgh, B.W., and Sprinkel, D.A., 2007, A new U$\mathrm{Pb}$ zircon age from an ash bed in the Brushy Basin Member of the Morrison Formation near Hanksville, UT [Abstract]: Geological Society of America, Abstracts with Programs, v. 39, p. 9.

Lécuyer, C., Grandjean, P., And Emig, C.C., 1996, Determination of oxygen isotope fractionation between water and phosphate from living lingulids: potential application to palaeoenvironmental studies: Palaeogeography, Palaeoclimatology, Palaeoecology, v. 126, p. $101-108$

LÉCUYER, C., 2004, Oxygen isotope analysis of phosphate, in Handbook of Stable Isotope Analytical Techniques: Amsterdam, Elsevier, p. 482-496.

Lécuyer, C., Bogey, C., Garcia, J.-P., Grandjean, P., Barrat, J.-A., Floquet, M., Nardet, N., and Pereda-Superbiola, X., 2003, Stable isotope composition and rare earth element content of vertebrate remains from the Late Cretaceous of northern Spain (Laño): did the environmental record survive?: Palaeogeography, Palaeoclimatology, Palaeoecology, 193, p. 457-471.

Levin, N.E., Cerling, T.E., Passey, B.H., Harris, J.M., and Ehleringer, J.R., 2006, A stable isotope aridity index for terrestrial environments: National Academies of Science, USA, Proceedings, v. 103, p. 11201-11205.

Ludvigson, G.A., Joekel, M., González, L.A., Gulbranson, E., Rasbury, T.R., Hunt, G., Kirkland, J., and Madsen, S., 2010, Correlation of Aptian-Albian carbon isotope excursions in continental strata of the Cretaceous foreland basin, eastern Utah, USA: Journal of Sedimentary Research, v. 80, p. 955-974.

MARKwick, J., 1998, Fossil crocodilians as indicators of Late Cretaceous and Cenozoic climates: implications for using palaeontological data in reconstructing palaeoclimate: Palaeogeography, Palaeoclimatology, Palaeoecology, v. 137, p. 205-271.

Menegatti, A.P., Weissert, H., Brown, R.S., Tyson, R.V., Farrimond, P., Stasser, S., and CARon, M., 1998, High-resolution $\delta^{13} \mathrm{C}$ stratigraphy through early Aptian "Livello Selli": Paleoceanography, v. 13, p. 530-545.

O’Neil, J.R., Clayton, R.N., and Mayeda, T.K., 1969, Oxygen isotope fractionation in divalent metal carbonates: Journal of Chemical Physics, v. 51, p. 5547-5558
O’Neil, J.R., Roe, R.R., Reinhard, E., and Blake, R.E., 1994, A rapid and precise method of oxygen isotope analysis of biogenic phosphate: Isreal Journal of EarthSciences, v. 43, p. 203-212.

Овон-Ikuenobe, F.E., Benson, D.G., Scott, R.W., Holbrook, J.M., Evetts, M.J., And ERBACHER, J., 2007, Re-evaluation of the Albian-Cenomanian boundary in the U.S Western Interior based on dinoflagellate cysts: Review of Palaeobotony and Palynology, v. 144, p. 77-97.

Pough, F.H., Janis, C.M., And Heiser, J.B., 2002, Vertebrate Life: Upper Saddle River, N.J., Prentice Hall, 699 p.

Poulsen, C.J., Barron, E.J., Peterson, W.H., and Wilson, P.A., 1999, A reinterpretation of Mid-Cretaceous shallow marine temperatures through model-data comparison: Paleoceanography, v. 14, p. 679-697.

Poulsen, C., David, P., and White, T.S., 2007, General circulation model simulation of the $\delta^{18} \mathrm{O}$ content of continental precipitation in the middle Cretaceous: a model-proxy comparison: Geology, v. 35, p. 199-202.

Robinson, S.A., Scotchman, J.I., White, T.S., And Atkinson, T.C., 2010, Contraints on palaeoenvironments in the Lower Cretaceous Wealden of southern England, from the geochemistry of sphaerosiderites: Geological Society of London, Journal, v. 167, p. 303-311.

Sander, P.M., Christian, A., Clauss, M., Fechner, R., Gee, C.T., Griebeler, E., Gunga, H.-C., Hummel, J., Mallison, H., Perry, S.F., Preuschoft, H., Rauhut, O.W.M., Remes, K., Tutken, T., Wings, O., and Witzel, U., 2011, Biology of the sauropod dinosaurs: the evolution of gigantism: Biological Reviews, v. 86, 117-155.

Shapiro, R.S., Fricke, H.C., and FoX, K., 2009, Dinosaur-bearing oncoids from ephemeral lakes of the Lower Cretaceous Cedar Mountain Formation, Utah: Palaios, v. 24 , p. $51-58$.

Sharp, Z.D., Atudorei, V., And Furrer, H., 2000, The effect of diagenesis on oxygen isotope ratios of biogenic phosphates: American Journal of Science, v. 300, p. 222 237.

Snell, K.E., Koch, P.L., Druschke, P., Foreman, B.Z., and Eiler, J.M., 2014, High elevation of the "Nevadaplano" during the Late Cretaceous: Earth and Planetary Science Letters, v. 386, p. 52-63.

SPICER, R.A., AND CoRfIEld, R.M., 1992, A review of terrestrial and marine climates in the Cretaceous with implications for modeling the "Greenhouse Earth": Geological Magazine, v. 2, p. 169-180.

Sprinkel, D.A., Madsen, S.K., Kirkland, J.I., WaAnders, G.L., and Hunt, G.J., 2012, Cedar Mountain and Dakota Formations around Dinosaur National Monument: evidence of the first incursion of the Cretaceous Western Interior Seaway into Utah: Utah Geological Survey, Special Study 143, $21 \mathrm{p}$.

Stokes, W.L., 1949, Morrison and related deposits in and adjacent to the Colorado Plateau: Geological Sociey of America, Bulletin, v. 55, p. 951-992.

Suarez, C.A., Suarez. M., Terry, D.O., JR., And Grandstaff, D.E., 2007, Rare earth element geochemistry and taphonomy of the early Cretaceous Crystal Geyser Dinosaur Quarry, East-Central Utah: Palaios, v. 22, p. 500-512.

Suarez, C., González, L.A., Ludvigson, G.A., Cifeldi, R.L., and Tremain, E., 2012, Water utilization of the Cretaceous Mussentuchit Member local vertebrate fauna, Cedar Mountain Formation, Utah, USA: using oxygen isotopic composition of phosphate: Palaeogeography, Palaeoclimatology, Palaecology, v. 313-314, p. 78-92. Suarez, M.B., Suarez, C., Kirkland, D.E., Grandstaff, D.E., González, L.A., and Terry, D.O., JR., 2007, Sedimentology, stratigraphy, and depositional environment of the Crystal Geyser Dinosaur Quarry, East-Central, Utah: Palaios, v. 22, p. 513-527.

Suarez, M.B., Gonzalez, L., Ludvigson, G., Vega, F.J., and Alvarado-Ortega, J., 2009 , Isotopic composition of low-latitude paleprecipitation during the Early Cretaceous: Geological Society of America, Bulletin, v. 121, p. 1584-1595.

Suarez, M.B., González, L.A., And Ludvigson, G.A., 2011, Quantification of a greenhouse hydrologic cycle from equatorial to polar latitudes: the mid-Cretaceous water bearer revisited: Palaeogeography, Palaeoclimatology, Palaeoecology, v. 307, p. $301-312$.

Ufnar, D.F., Gonzalez, L., Ludvigson, G., Brenner, R.L., and Witzke, B.J., 2002, The mid-Cretaceous water bearer: isotope mass balance quantification of the Albian hydrologic cycle: Palaeogeography, Palaeoclimatology, Palaeoecology, v. 188, p. 5171 .

Ufnar, D.F., Gonzalez, L.A., Ludvigson, G.A., Brenner, R.L., and Witzke, B.J., 2004, Evidence for increased latent heat transport during the Cretaceous (Albian) greenhouse warming: Geology, v. 32, p. 1049-1052.

Vennemann, T.W., Fricke, H.C., Blake, R.E., O’Neil, J.R., and Colman, A., 2002, Oxygen isotope analysis of phosphates: a comparison of techniques for analysis of $\mathrm{Ag}_{3} \mathrm{PO}_{4}$ : Chemical Geology, v. 185 , p. 321-336

White, T., Gonzalez, L., Ludvigson, G., And Poulsen, C., 2001, Middle Cretaceous greenhouse hydrologic cycle of North America: Geology, v. 29, p. 363-366.

Wilkinson, M., Gilfillan, S.M.V., Haszeldine, S., and Ballentine, C.J., 2009, Plumbing the depths: testing natural tracers of subsurface $\mathrm{CO}_{2}$ origin and migration, Utah, USA, in Grobe, M., Pashin, J.C., and Dodge, R.L. eds., Carbon Dioxide Sequestration in Geological Media: State of the Science: American Association of Petroleum Geologists, Special Publication 59, p. 619-634.

Wolfe, J.A., And Upchurch, G., 1987, North American nonmarine climates and vegetation during the Late Cretaceous: Palaeogeography, Palaeoclimatology, Palaeoecology, v. 61, p. 33-77.

Received 28 August 2013; accepted 18 July 2014. 